\title{
The Stebnyk Formation (Miocene) in the Boryslav-Pokuttya and Sambir nappes of the Ukrainian Carpathians: a record of environmental change in the Carpathian Foredeep
}

\author{
Nestor OSZCZYPKO ${ }^{1}$, Alfred UCHMAN ${ }^{1, *}$ and Ihor BUBNIAK ${ }^{2}$ \\ 1 Jagiellonian University, Institute of Geological Sciences, Oleandry 2a, 30-063 Kraków, Poland \\ 2 Ivan Franko National University of Lviv, Geological Faculty, Hrushevskyi 4, 79005 Lviv, Ukraine
}

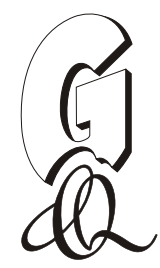

\begin{abstract}
Oszczypko, N., Uchman, A., Bubniak, I., 2016. The Stebnyk Formation (Miocene) in the Boryslav-Pokuttya and Sambir nappes of the Ukrainian Carpathians: a record of environmental change in the Carpathian Foredeep. Geological Quarterly, 60 (2): 473-492, doi: 10.7306/gq.1290

The late Early-Middle Miocene Stebnyk Formation is a $~ 600-2000 \mathrm{~m}$ thick unit of the Boryslav-Pokuttya and Sambir nappes, which contains a molasse succession of the Carpathian Foredeep incorporated within the marginal part of the Outer Eastern Carpathian accretionary wedge. In the valley of the Prut River, between Deliatyn and Lanchyn, the Stebnyk Formation overlies the alluvial fan deposits of the Sloboda Conglomerate and the deltaic deposits of the Dobrotiv Formation in the south, and the lagoonal salty clays of the Vorotyshcha Formation in the north. The Stebnyk Formation is built of mainly rose, greenish and grey calcareous mudstones intercalated with several variable sandstone beds, including thick-bedded packages. The occurrence of tetrapod footprints and raindrop imprints, as well as the overall red-bed character reflect prevailing continental conditions during deposition of the formation, which is interpreted as sediments of a delta plain with distributary channels infilled with thick sandstone beds and associated with intercalations of thinner beds referred to channel levees and crevasse splays. The upper part of the Stebnyk Formation contains marine microfossils of the NN4 Zone, and locally of the NN5 Zone, corresponding to the Early Badenian transgression in the region. On a regional scale, the Stebnyk Formation shows a polarity of facies, with a large contribution of conglomerates and thick-bedded sandstones in the lower part in the north-west and fining to the south-east, with transport from the west and north-west. The sediments accumulated in an elongated subsiding zone between the rising Carpathian orogen and the forebulge elevation of the foreland, in warm and semi-dry climatic conditions corresponding roughly to the Middle Miocene Climatic Optimum. The accumulation was balanced by a subsidence caused by sinking of the platform slab and by sedimentary loading.
\end{abstract}

Key words: non-marine, delta plain, molasse, Middle Miocene Climatic Optimum, Carpathian Foredeep, Ukraine.

\section{INTRODUCTION}

The Stebnyk Formation (Early-Middle Miocene) is a characteristic lithostratigraphic unit of the Boryslav-Pokuttya and Sambir nappes of the Outer Eastern Carpathians in Ukraine. According to Tołwiński (1950), the Stebnyk Formation, between Przemyśl (Poland) and Kolomyia in Ukraine (ca. 200 km) occurs in a belt up to $20 \mathrm{~km}$ wide; it became abruptly narrower to the south-east, down to $250 \mathrm{~m}$ at the Rybnytsia Valley near Kosiv. Its deposits, dominated by variegated marly mudstones intercalated with sandstones, with significant contributions of conglomerates in the west, typically as red beds, and showing evidence of marine influence in its upper part, record a significant change in depositional palaeoenvironment during the final stage of development of the Inner Carpathian Foredeep. How-

\footnotetext{
*Corresponding author, e-mail: alfred.uchman@uj.edu.pl
}

Received: February 3, 2016; accepted April 2, 2016; first published online: April 12, 2016 ever, its depositional palaeoenvironment has never been subject to closer analysis.

The aim of this paper is: 1) to describe facies features of the Stebnyk Formation in the valley of the Prut River, between Lanchyn and Deliatyn, as well as in the western bank of the Bystrytsia Nadvirnanska River near Nadvirna (Fig. 1), and 2) to interpret the palaeoenvironmental conditions of this formation in the context of the foredeep basin evolution and with reference to previous publications on the underlying deposits (Oszczypko et al., 2012, 2014). The best exposures, characterized by good continuity and covering altogether the whole formation, have been selected for these studies. Furthermore, a review of research into the Stebnyk Formations is compiled, because of its long and complex history of study and dispersal in the literature.

\section{GEOLOGICAL SETTING}

Along the marginal part of the Ukrainian Carpathians, a wide zone of folded Miocene deposits belongs to the Boryslav-Pokuttya and Sambir nappes (Fig. 1B, C). The Boryslav-Pokuttya Nappe, known also as the Marginal Fold Unit or the 


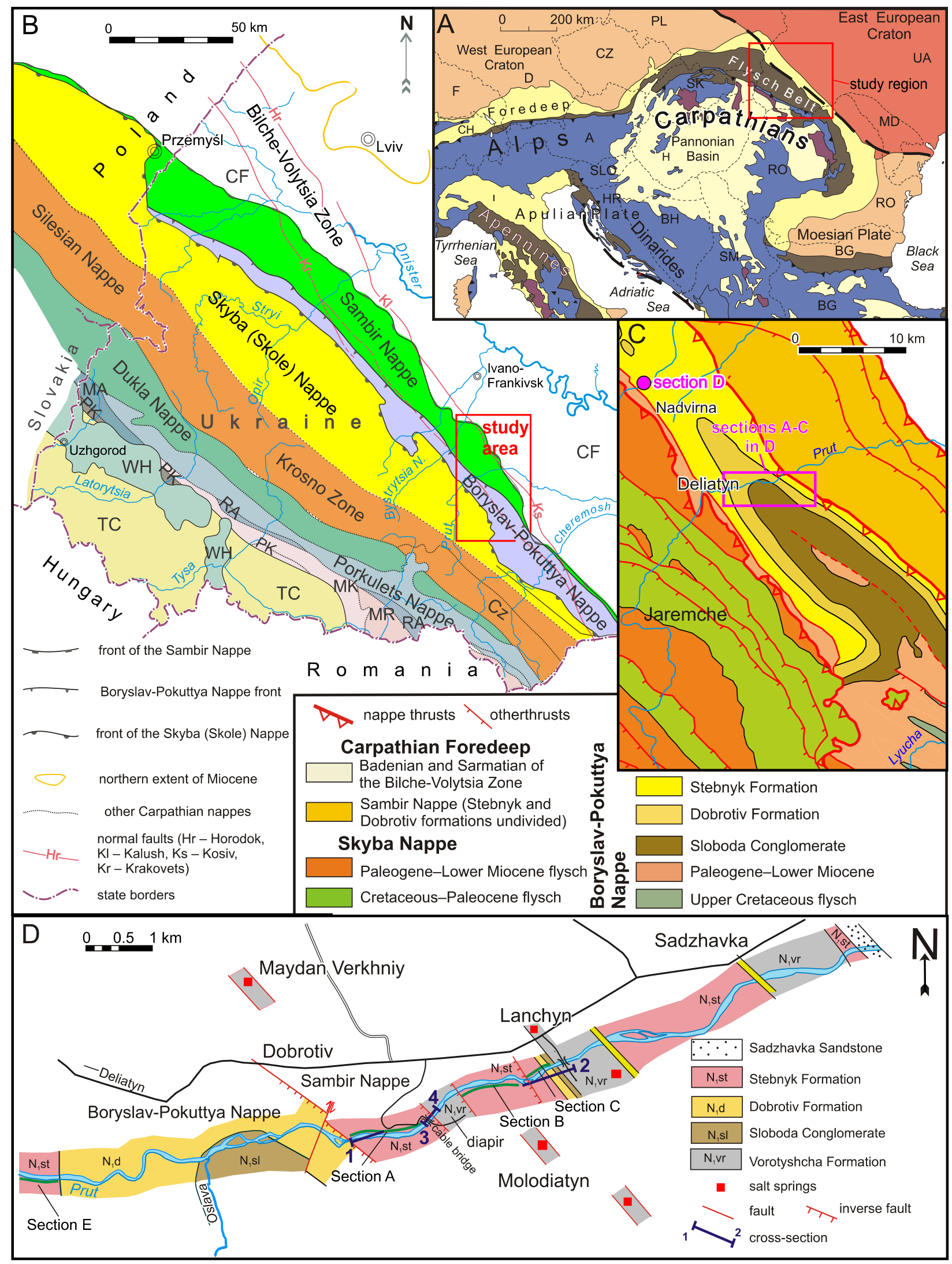

Fig. 1. Location maps

A - position of the study area in the Alpine-Carpathian system (after Picha, 1996, modified by Oszczypko et al., 2006); B - tectonic map of the Ukrainian Carpathians (after Ślaczka et al., 2006, simplified); CF - Carpathian Foredeep, CZ - Chornohora Nappe, MA - Magura Nappe, MK - Marmarosh Klippen Zone, MR - Marmarosh Massif, PK - Pieniny Klippen Belt, RA - Rakhiv Nappe, TC - Trans-Carpathian Depression, WH - Vihorlat-Gutin Volcanic Massif; C - geological map of Deliatyn-Lanchyn-Nadvirna area (after Matskiv et al., 2009, simplified), showing location of section D and the study area; D - geological sketch-map along the Prut River showing location of the cross-sections 1-2, $3-4$, and sections A-E (the map partly after Bujalski, 1938) 
Boryslav-Pokuttya Folds, is exposed in a narrow (up to $20 \mathrm{~km}$ ) belt located between the Skyba (Skole) and Sambir nappes. This nappe is traced from Romania in the SE up to the Polish border in the NW. It is built of a complex set of superimposed thrust sheets (Koltun et al., 2005). The Boryslav-Pokuttya Nappe, composed of flysch and molasse deposits, descends beneath the frontal Carpathian overthrust of the Sambir Nappe, which comprises exclusively molasse deposits. Strata of the Boryslav-Pokuttya and Sambir nappes represent the deformed part of the inner Carpathian Foredeep, which is thrusted over the Middle Miocene (Badenian and Sarmatian) autochthonous deposits of the Bilche-Volytsia Zone resting directly on the foreland platform basement (Burov et al., 1978; Smirnov et al., 2000).

\section{BORYSLAV-POKUTTYA NAPPE}

This nappe is subdivided into the Deliatyn and Runhury Sloboda sub-nappes (Kulchytsky et al., 1997; Matskiv et al., 2009). The Deliatyn Sub-nappe is composed of Cretaceous-Lower Miocene flysch, which is similar to that of the Skyba Nappe. The youngest Lower Miocene flysch succession belongs to the Polanytsia Formation, which is overlain by the Vorotyshcha Formation (NN3-?NN4 Zone; Andreyeva-Grigorovich et al., 2008a). The Vorotyshcha Formation, up to $700 \mathrm{~m}$ thick, composed of grey mudstones-siltstones intercalated with coarse-grained sandstones and conglomerates, contains large blocks of impure halite and anhydrite (Tołwiński, 1950; Gurzhyi, 1969; Andreyeva-Grigorovich et al., 2008a). Locally, the middle and upper parts of the Vorotyshcha Formation are replaced by the Sloboda Conglomerate and Dobrotiv Formation (Oszczypko et al., 2012, 2014 and references therein; Fig. 2).

The Deliatyn Sub-nappe, overthrusted upon the Runhury Sloboda Sub-nappe, is built mainly of deposits of the Sloboda Conglomerate (Oszczypko et al., 2012), Dobrotiv Formation (Oszczypko et al., 2014) and the Stebnyk Formation (this paper). Several boreholes showed that the Sloboda Conglomerate is underlain by the Vorotyshcha Formation, which overlies flysch deposits of the upper part of the Menilite and Polanytsia formations, represented mainly by olistoliths, olistostromes, and olistoplaques (Kolodiy et al., 2004).

In the southern limb of the Runhury Sloboda Anticline, the Sloboda Conglomerate is underlain by the Menilite Formation (Oligocene), and in its northern limb by salt clays of the Vorotyshcha Formation (Tołwiński, 1950). The Sloboda Conglomerate contains exotic blocks, boulders and cobbles of Upper Proterozoic-Lower Paleozoic green phyllite, black schist, dolomite, Jurassic white limestone and rare, flysch-derived olistoliths and olistostromes (Fedushchak, 1962; Oszczypko et al., 2012). The thickness of the Sloboda Conglomerate increases from 450-500 m in the Nadvirna area up to $1400 \mathrm{~m}$ at Runhury Sloboda. The Sloboda Conglomerate passes into the mudstones, siltstones and sandstones of the ?Ottnangian Dobrotiv Formation, which is up to $800 \mathrm{~m}$ thick. This formation is followed by the Stebnyk Formation (Karpatian-Lower Badenian; see

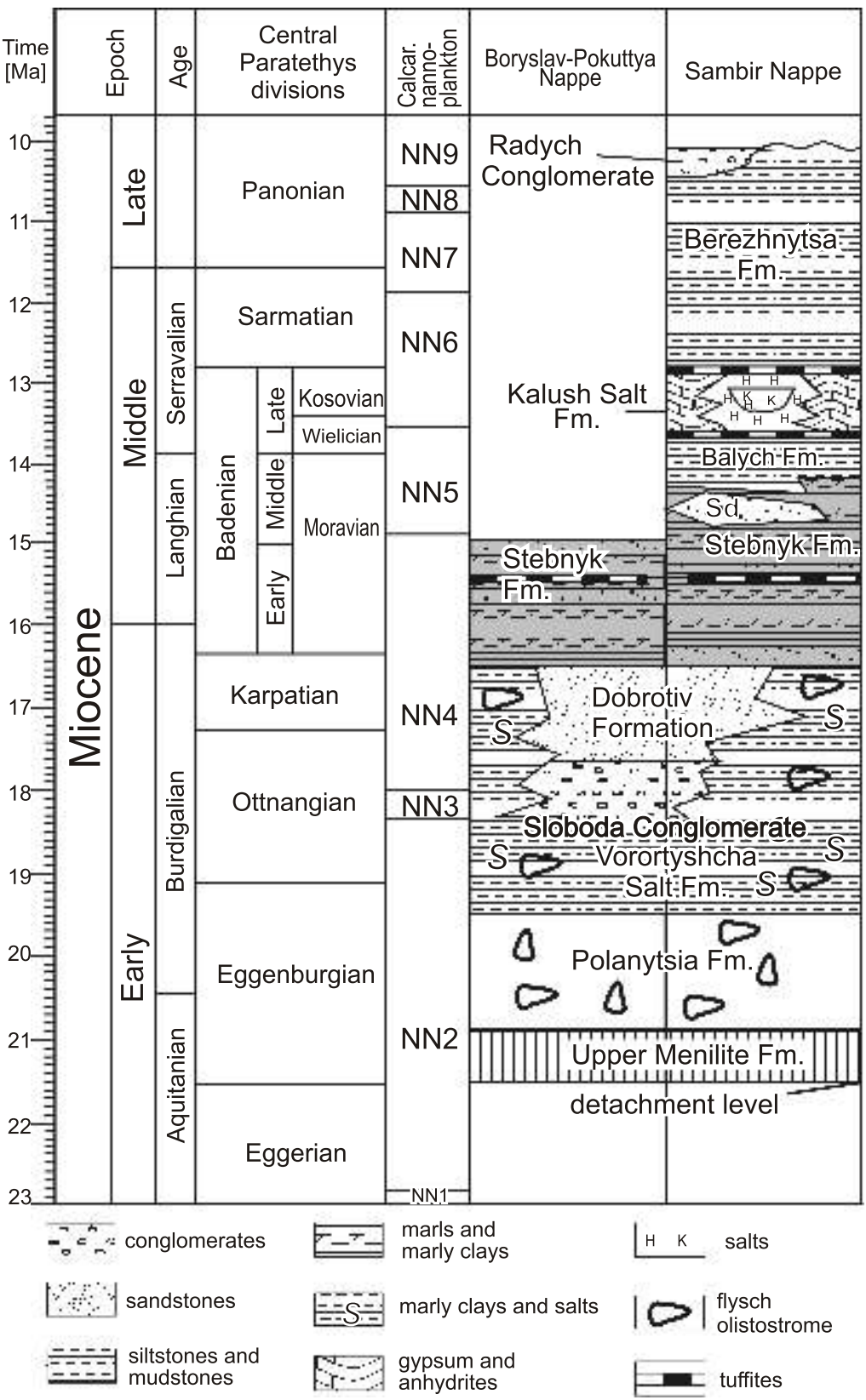

Fig. 2. Lithostratigraphic scheme of the Boryslav-Pokuttya and Sambir nappes in the study area (based on Oszczypko et al., 2014, supplemented)

\section{Sd - Sadzhavka Sandstone}

Andreyeva-Grigorovich et al., 1995, 1997, 2008a, b). On the northern limb of the Runhury Sloboda Anticline, at Jabloniv, gypsum-bearing beds up to $100 \mathrm{~m}$ thick are sandwiched between the Sloboda and Dobrotiv formations (Tołwiński, 1950).

A fundamentally different stratigraphic scheme of the Boryslav-Pokuttya Nappe was proposed by Smirnov (2003). In his interpretation, the Boryslav-Pokuttya succession begins with the upper part of the Menilite Formation (Eggerian), which is followed by the Polanytsia Formation (Eggenburgian) with the Rushor Conglomerate at its base, and is terminated by the Vorotyshcha Formation (Ottnangian) with the Truskavets Conglomerate at its base. In this interpretation, the Miocene deposits of the Sambir Nappe begin with the Sloboda Conglomerate (Eggerian), which is followed by the Dobrotiv Formation 
(Eggenburgian/Ottnangian). These deposits pass upwards into the undivided Kalush succession, which is up to $2000 \mathrm{~m}$ thick (Ottnangian-Middle Badenian). Its lower part is composed of the Stebnyk facies (rose and variegated, marly mudstones and sandstones) followed by grey and "blue deposits" of the Balych facies. This succession is terminated by the Kalush salts and gypsum deposits.

\section{SAMBIR NAPPE}

The Sambir Nappe, up to $24 \mathrm{~km}$ wide and composed of several thrust-sheets (Fig. 1), is correlated with the Sub-Carpathian Unit in Romania and the Stebnik Unit in SE Poland (Oszczypko et al., 2006, 2008). This unit is thrusted over the Badenian-Sarmatian deposits of the outer Carpathian Foredeep (Kolodiy et al., 2004). The Sambir Nappe succession is composed mainly of a thick succession of the "lower" Miocene molasse of the Stebnyk and Balych formations. The lithostratigraphy of its basal part is still under discussion. Several authors (Koltun et al., 2005; Andreyeva-Grigorovich et al., 2008b and references therein) regard the Vorotyshcha Formation as the oldest division of the Sambir Nappe succession. This opinion is supported by data from boreholes, e.g. Hvizd 1 near Nadvirna, and Urych 6 (NE of the Boryslav), where the Vorotyshcha Formation was penetrated (Andreyeva-Grigorovich et al., 1997, 2008a). Coarse clastic deposits of the Sloboda Conglomerate and the mudstone-sandstone Dobrotiv Formation occur in this unit in a residual form. In the Prut Valley, the last large exposures of the Sloboda Conglomerate and Dobrotiv Formation are present between the Oslava and the Chorna rivers, which are the right-side tributaries of the Prut River. An exposure of the latest formation several tens of metres long is also known from the Prut River banks close to the Lanchyn bridge (Figs. 1 and 3A, see also Bujalski, 1934; Andreyeva-Grigorovich et al., 2008a; Oszczypko et al., 2012, 2014).

The Dobrotiv Formation is followed by variegated marls, mudstones and sandstones of the Stebnyk Formation (Karpatian-Middle Badenian; Andreyeva-Grigorovich et al., 2008a).
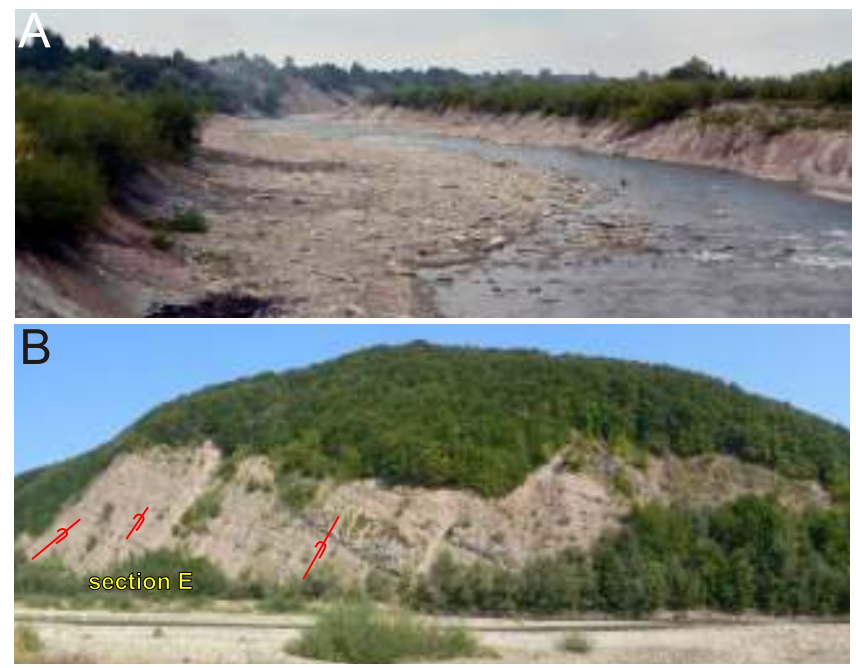

Fig. 3. Views of exposures of the Stebnyk Formation

A - exposures along the Prut River between Dobrotiv and Lanchyn (section B); view down the river; B - large exposure along the left bank of the Bystrytsia Nadvirnanska River at Nadvirna (section D); inverted beds in an antiformal syncline; measured section $E$ indicated by a series of bars
The overlying Balych Formation passes upwards into the Bohorodchany Formation (Andreyeva-Grigorovich et al., 1997). In the Kalush area, the Stebnyk and Balych formations are undivided and they pass upwards into the Bohorodchany Formation, which is composed of 100-250 m thick, grey marly mudstones and sandstones. They contain rich Badenian planktonic foraminifera and calcareous nannoplankton of the NN5 Zone (Andreyeva-Grigorovich and Kulchytsky, 1985; Andreyeva-Grigorovich et al., 2003). In the Kalush area, the undivided Stebnyk and Balych formations are followed by salt deposits of the Kalush Formation. This formation is contemporaneous with the Wieliczka (Poland) and Tyras evaporitic formations (Bilche-Volytsia Zone, Ukraine) belonging to the NN5/NN6 zones (Andreyeva-Grigorovich et al., 2003; Fig. 2).

Near Dobromyl, in the NW part of Sambir Nappe, the youngest deposits belonging to the Kosiv (Upper Badenian) and Dashava (Sarmatian) formations have been documented. The Dashava succession (Berezhnytsia Formation after Hnylko, 2014) is terminated by the Radych Conglomerate, which contains flysch clasts. The age of these deposits is dated to the NN6-NN9 zones (Andreyeva-Grigorovich et al., 2008a).

\section{PREVIOUS WORK}

Paul and Tietze (1877: p. 68) mentioned red clays associated with salt clays between Nadvirna and Deliatyn, which have also been called "red clays" (Zuber, 1882), "red shales" (Zuber, 1888, 1915; Cizancourt, 1925; Bruderer, 1926), "shales with layers/beds of sandstones" (Zuber, 1882, 1883; Świderski, 1925), red "septarian beds" and "rose marls" (Jabłoński, 1923), "Miocene red shales" (Jabłoński and Weigner, 1925) or "variegated marls" (Bujalski, 1930). Tołwiński (1927) distinguished them as the Stebnyk Beds, but he used also the term "rose marls" or "variegated marls" (see also Tołwiński, 1937). Khadykin and Shakin (1976) used the name Stebnyk Formation and this name was used in the later literature. The Stebnyk Formation was characterized by almost all the Polish and Ukrainian geologists working in the study region (e.g., Zuber, 1888, 1915, 1918; Teisseyre, 1927; Bujalski, 1930, 1934, 1938; Tołwiński, 1950; Vialov, 1951, 1960, 1965, 1966; Gurzhyi, 1969 and references therein), who focused mainly on its stratigraphic position, lithology and palaeontological features. In Romania, the Stebnyk Formation counterparts are known in the Marginal Fold Unit and the Sub-Carpathian Unit as the Hirja and the Magiresti beds, respectively (Micu, 1982). The Stebnyk Formation is distinguished also in SE Poland (under the name Stebnik Beds) in the prolongation of the Sambir Nappe, which is called here the Stebnik Unit (Głowacki et al., 1966; Ney, 1968; Ney et al., 1974; Garecka and Olszewska, 1997; Olszewska, 1999 and references therein).

The most detailed descriptions of the Stebnyk Formation are given by Teisseyre (1927), Tołwiński (1927, 1950), Bujalski (1934), Vialov (1965), Gurzhyi (1969), and Khruschov and Kompanets (1988). Vialov (1965) proposed that the transition between the Dobrotiv and the Stebnyk formations is gradual and the boundary is conventionally proposed at the base of the first "rose marls", while the boundary between the Stebnyk Formation and the overlying Balych Formation at Sadzhavka in the Prut Valley is at the base of a $40 \mathrm{~m}$ thick succession composed of poorly cemented, massive sandstone beds (up to $5 \mathrm{~m}$ thick) intercalated with grey, green-grey and rose calcareous mudstones, distinguished as the Sadzhavka Sandstone (Berlyavskiy in Vialov, 1951, 1965). Vialov (1965) regarded these sandstones as the "northern facies" of the upper part of the Stebnyk Formation, and Gurzhyi (1969) as the upper part of the 
Stebnyk Formation. Different thicknesses of the formation are reported in the literature: 1000-1500 m (Tołwński, 1927), 600-2000 m (Gurzhyi, 1969), 500-1000 (Hnylko, 2004), up to $1200 \mathrm{~m}$ in SE Poland (Ney et al., 1974), or 800-1200 m in the Boryslav-Pokuttya Nappe and 500-1000 m in the Sambir Nappe (Andreyeva-Grigorovich at al., 2011).

In the study area, Cizancourt (1925) distinguished three facies types in the Stebnyk Formation (his "red shales"):

- the Strutyn type: brick-coloured or chocolate-red marls, rich in mica, with intercalations of grey-greenish sandstones and "traces" of gypsum;

- the Nadvirna type: micaceous, vine-red shales intercalated with cross-bedded, micaceous sandstones, which are $10-50 \mathrm{~cm}$ thick;

- the Petranka type: $20-100 \mathrm{~cm}$ thick beds of sandy, micaceous, red-greenish or rose marls, with common greenish spots, gypsum crystals, locally with intercalations of cross-bedded sandstones.

Vialov (1965) and Gurzhyi (1969) noticed a lateral facies change in the Stebnyk Formation more widely, with a significant contribution of conglomerates (Vyrva River facies, according to Vialov, 1965) and thick-bedded sandstones in the north-west, which became thinner and rarer toward the south-east, and with a transition to more clayey facies with more frequent occurrences of gypsum, with salt lenses (e.g., the potash salts at Kalush), and finally with the salty shale "blue (Lanchyn) facies" further in this direction, similar to the salt-bearing Vorotyshcha Formation. Zuber (1883) had reported that the red shales are partly replaced by grey green shales to the south-east. Vialov (1965) and Gurzhyi (1969) considered the Dubnik Conglomerate in the Stebnik Unit in SE Poland as the lowest part of the Stebnyk Formation. Conglomerates are known from the lower part of the Stebnyk Formation from boreholes south of Przemyśl in SW Poland (Głowacki et al., 1966). In the boreholes Nyzhankovychi-1 and Chyzhky-1 (both very close to the Polish border), a thick conglomerate (255 m and 550-600 m, respectively) occurs at the base of the Stebnyk Formation, with thinner packages of conglomerates higher in the formation (Gurzhyi, 1969; Burov et al., 1976; Khadykin and Shakin, 1976). The conglomerates contain material both from the platform (mainly phyllites) and from the flysch of the Carpathians. The facies changes are related to changes in palaeomorphology (Vialov, 1965). These views must be corrected according to newer stratigraphic researches (Andreyeva-Grigorovich et al., 2003, 2008a, 2011), which shows that the potash salts at Kalush are distinctly younger (Upper Badenian, NN6 Zone) than the Stebnyk Formation. Also, Garlicki (1973) did not find any salt deposits in the Stebnyk Formation south of Przemyśl in SE Poland. According to Ney (1968) and Ney et al. (1974), the Stebnik Beds (= Stebnyk Formation) in SE Poland are up to 1200 m thick; in the lower part $(500 \mathrm{~m})$, they composed mostly of sandstones, commonly cross-laminated, with many lithic grains, and lenses of conglomerates, intercalated with grey, rose of brown mudstones, while the upper part is dominated by rose and brown-rose mudstones, with intercalations of sandstone and fine conglomerate.

The most detailed lithological characteristics of the Stebnyk Formation were given by Gurzhyi (1969). According to this author, the Stebnyk Formation mudstones, mostly parallel laminated, contain (mean) 15-20\% $\mathrm{CaCO}_{3}$, and were deposited in a shallow lagoon, with periodic precipitation of gypsum and potassium salt lenses at Kalush, Morschyn, Lanchyn and Utoropy. Fine- and medium-grained sandstones contain up to $80-85 \%$ of quartz, with muscovite and calcite, and rarely pyroclastic grains (Gurzhyi, 1969). Moreover, dolomite, gypsum (also in veins, see Zuber, 1882, 1888; Cizancourt, 1925), celestine, barite and glauconite can be present (Koltun in Vialov, 1965). Teisseyre (1939) noticed phyllite grains in the sandstones. Coarse sandstones contain up to $30-40 \%$ lithic grains, interpreted as evidence of short transportation. The cement can constitute $10-50 \%$ of the rock; it can be calcareous-clayey (up to $40-45 \% \mathrm{CaCO}_{3}$ ) to noncalcareous clayey (Gurzhyi, 1969).

The Stebnyk Formation contains some intercalations of dacite tuffites, the thickness of which oscillate from 10 to $25 \mathrm{~cm}$ in the Nadvirna section (Gurzhyi, 1969). At Seredniy Maydan near Lanchyn these rocks (Bujalski, 1934, 1938) are 8-10 m thick (Vialov, 1965). Two beds of dacite tuffite at Krasna, $3.5 \mathrm{~km}$ NE of Dobrotiv (Kamieński, 1936) reach $20 \mathrm{~m}$ and 40-45 m in thickness (Vialov, 1965). The sandstones of the Stebnyk Formation (e.g., at Deliatyn, Nadvirna and Lanchyn) are known from the presence of copper mineralisation (that at Nadvirna was known already to Paul and Tietze, 1877, and to Zuber, $1882,1885,1888,1915)$, which may correspond to layers rich in plant detritus (Gurzhyi, 1969).

Variegated mudstones in the upper part of the Stebnyk Formation contain foraminifers of the Porosonanion insignis Zone (Vialov, 1965; Pishvanova, 1969) and other Miocene taxa (Głowacki et al., 1966) which, together with nannoplankton, point to the Late Karpatian-Early Badenian (NN4 Zone; Andreyeva-Grigorovich et al., 1997) and locally to the Middle Badenian (NN5 Zone), suggesting a diachronous boundary with the overlying Balych Formation (Andreyeva-Grigorovich et al., 2008a). Lateral transition between these formations had been suggested already by Bujalski (1930) who placed the Balych Formation within the upper part of the Stebnyk Formation. Foraminifers (see also Głowacki et al., 1966; Łuczkowska in Ney, 1968) and nannoplankton of the NN4 Zone have also been found in the upper part of the Stebnyk Formation in the Stebnik Unit in SE Poland (Garecka and Olszewska, 1997). In the middle part of the formation, algae (Characea) and ostracods (Loxoconcha dromax Liventul) occur; sponge spicules, radiolaria or echinoid spines, which can be found in some horizons, are probably redeposited (Vialov, 1965; Głowacki et al., 1966). In some borehole, Gurzhyi (1969) reported a few centimetre-thick limestone intercalations, which contain fragments of foraminifers, radiolaria, crinoids, and sponge spicules.

Several authors reported sedimentary structures and other sedimentary features in the Stebnyk Formation, which were summarized by Vialov (1965), Gurzhyi (1969) and Khrushchov and Kompanets (1988). They include cross-bedding (noticed already by Cizancourt, 1925), the lenticular character of some sandstone beds (1.5-2.0 m long, 15-20 cm thick; Vialov, 1965), amalgamation of beds, the presence of ripple marks, mudcracks, raindrop imprints, sand dykes and concretions (small calcareous concretions of septarian type - see Tołwiński, 1927; calcareous concretions up to $0.5 \mathrm{~m}$ across - see Gurzhyi, 1969). Khrushchov and Kompanets (1988) distinguished four different facies referred to the Stebnyk Formation and referred them to different deltaic and marine environments.

The Stebnyk Formation is known from vertebrate trace fossils summarized in Vialov (1966 and references therein) and Kulchytsky and Kulchytsky (1980). Hizhniakov (1954) recognized two artiodactyl mammal footprints ascribed to the Ovinae and Susidae at Nadvirna. Vialov (1966) determined one of them as Pecoripeda (Ovipeda) djali Vialov. Vialov (1965) noticed footprints and trackways of artiodactyl mammals and footprints of large birds in the lower part of the Stebnyk Formation in the Prut Valley section, and in the underlying Dobrotiv Formation. Vialov $(1965,1966)$ also reported Skolithos, interpreted as a shallow marine trace (Vialov, 1965). Among bird footprints, Vialov $(1960,1966)$ determined Avipeda phoenix Vialov, Avipeda sirin Vialov (both also in 
Kulchytsky and Kulchytsky, 1980), and Avipeda filiportatis Vialov. Mammal footprints include Pecoripeda (Ovipeda) djali Vialov, Pecoripeda sp. 1 (Vialov, 1966), forms similar to Bestiopeda sanguinolenia Vialov, Pecoripeda (Gazellipeda) gazella Vialov (Kulchytsky and Kulchytsky, 1980). The latest cited authors described also a fragment of jaw of a mammal belonging to the Bovidae and determined it as Hippidea parva Kulchytsky. Also a fragment of jaw of Hypsodontus (Bovidae) was found in the lower part of the Stebnyk Formation at Yabloniv (Kulchitsky and Smirnov, 1996).

The litho- and biostratigraphy of the Stebnyk Formation in the Prut Valley (Dobrotiv, Lanchyn) has been studied by Andreyeva-Grigorovich et al. (2008a, b, 2011), who recognized calcareous nannoplankton zone NN4 (Karpatian) in the Boryslav succession and NN4 (Karpatian) and NN5 (Early Badenian) zones in the Dobrotiv section (Sambir succession), in the lower and upper parts of the formation, respectively (Fig. 2). These authors reported intercalations of thick-bedded sandstones (1.5-2.0 m) with large-scale trough cross-bedding in the lower part of the Stebnyk Formation, which shows palaeotransport from the WNW $\left(290-300^{\circ}\right)$. Andreyeva-Grigorovich et al. (2011), based on calcareous nannoplankton and pelagic foraminifers, introduced a new Neogene stratigraphic scheme for the Ukrainian Carpathians and its foredeep. In this interpretation, the boundaries of almost all formations were recognized as diachronous. This interpretation was followed by Kulyanda and Hnylko (2012) who studied foraminifers from the Boryslav-Pokuttya and Sambir successions near Dobromyl, close to the Ukrainian/Polish boundary. In their opinion, the youngest part of the Vorotyshcha Formation belongs to the Karpatian, while the boundaries between the Vorotyshcha and Stebnyk formations are diachronous.

Tołwiński (1950) reported salt diapirs crossing the Stebnyk Formation, accompanied by salt brine springs, e.g. at Lanchyn. Between Dobrotiv and Lanchyn (see also Zuber, 1888; Tołwiń- ski, 1927; Bujalski, 1938), Świderski (1925) noticed that the "salt clays" come out from under "red shales and sandstones". According to Tołwiński (1950), some salt brine springs in the area may also point to a shallow occurrence of salt clays of the Vorotyshcha Formation. Hnylko (2001, 2012, 2014; see also Vashchenko and Hnylko, 2003) distinguished the Lanchyn Olistostrome surrounded by the Stebnyk Formation. According to this author, the Middle Miocene Lanchyn Olistostrome belongs to the Balych Formation, developed at the front of the Boryslav-Pokuttya Nappe. Earlier, from the same locality (a section close to the cable bridge at Dobrotiv), the salt-bearing deposits have been described as the Vorotyshcha Olistostrome included in the upper part of the Stebnyk Formation (Andreyeva-Grigorovich et al., 2008a).

\section{SECTIONS STUDIED}

The studied sections A-C, E of the Stebnyk Formation are located in the Prut Valley (Fig. 1D), between the villages of Dobrotiv and Lanchyn, where almost continuous exposures are present over a distance of several kilometres along the river banks (Fig. 3A). These exposures display folded Miocene deposits of the Boryslav-Pokuttya and Sambir nappes (see Oszczypko et al., 2012, 2014). However, the boundary between the Boryslav-Pokuttya and Sambir nappes is unclear, because it is marked inside of the Stebnyk Formation in the northern limb of the Runhury Sloboda Anticline, ca. $1 \mathrm{~km}$ below inflow of the Oslava River (Fig. 1C; see geological maps by Jankowski et al., 2007; Matskiv et al., 2009; Hnylko, 2012) without any clear evidence. Additionally, the Stebnyk Formation was studied in the Nadvirna area in the section D (Boryslav-Pokuttya Nappe; Fig. 3B). According to Hnylko (2012, 2014), the Lanchyn Olistostrome is located between
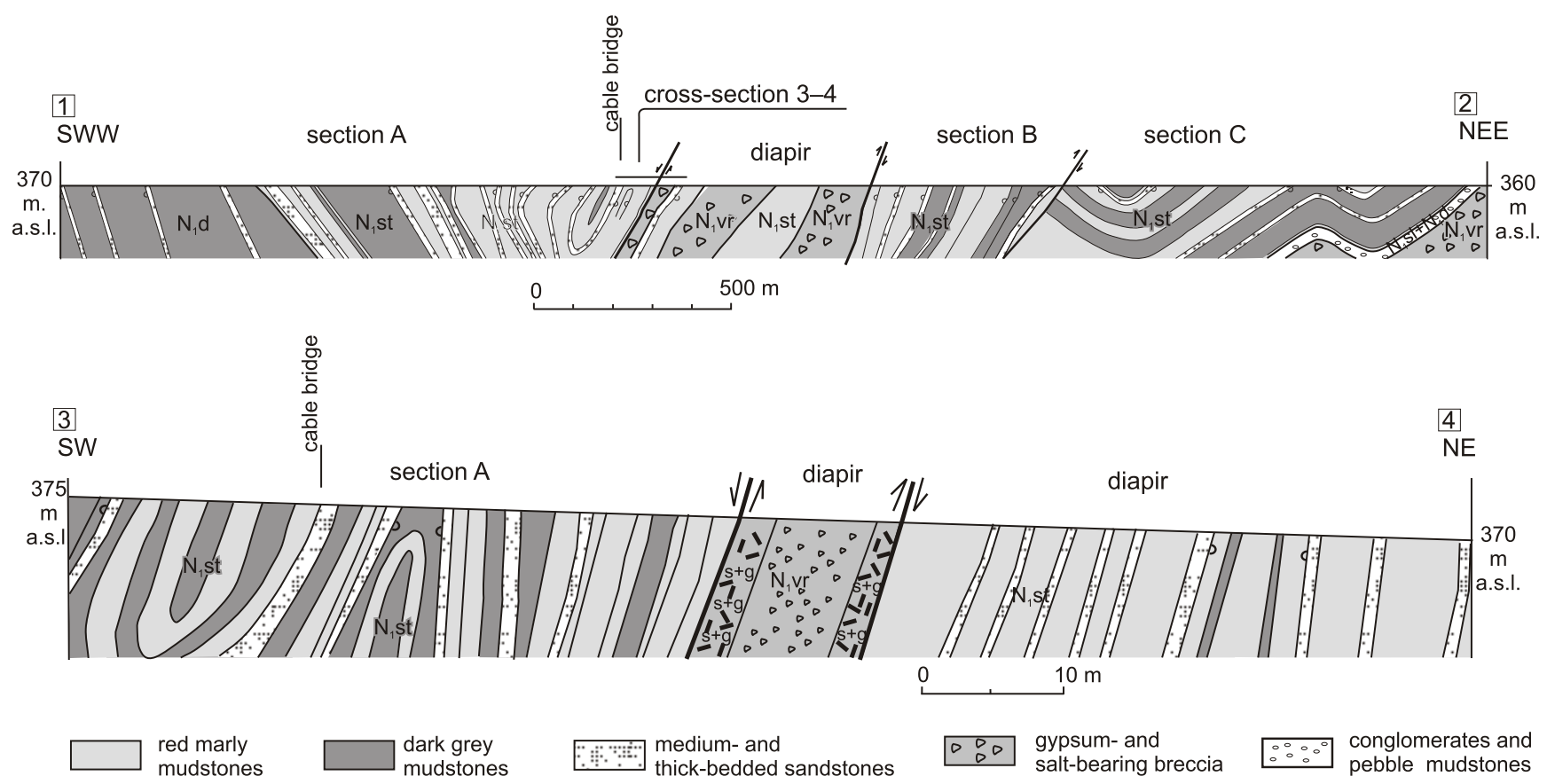

Fig. 4. Geological cross-section 1-2 along the Prut River between Dobrotiv and Lanchyn, and geological cross-section 3-4 through the Stebnyk Formation close to the cable bridge on the Prut River near Dobrotiv 
Section A

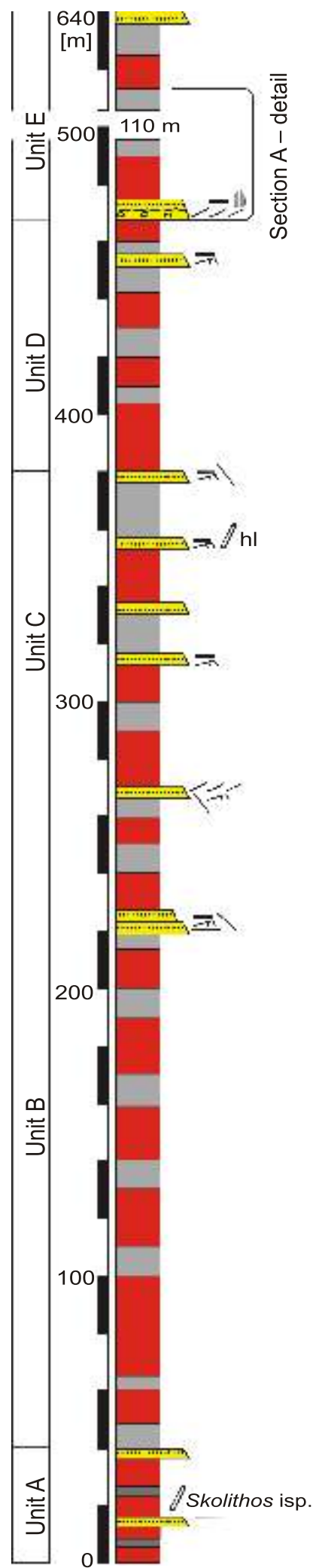

Section A - detail

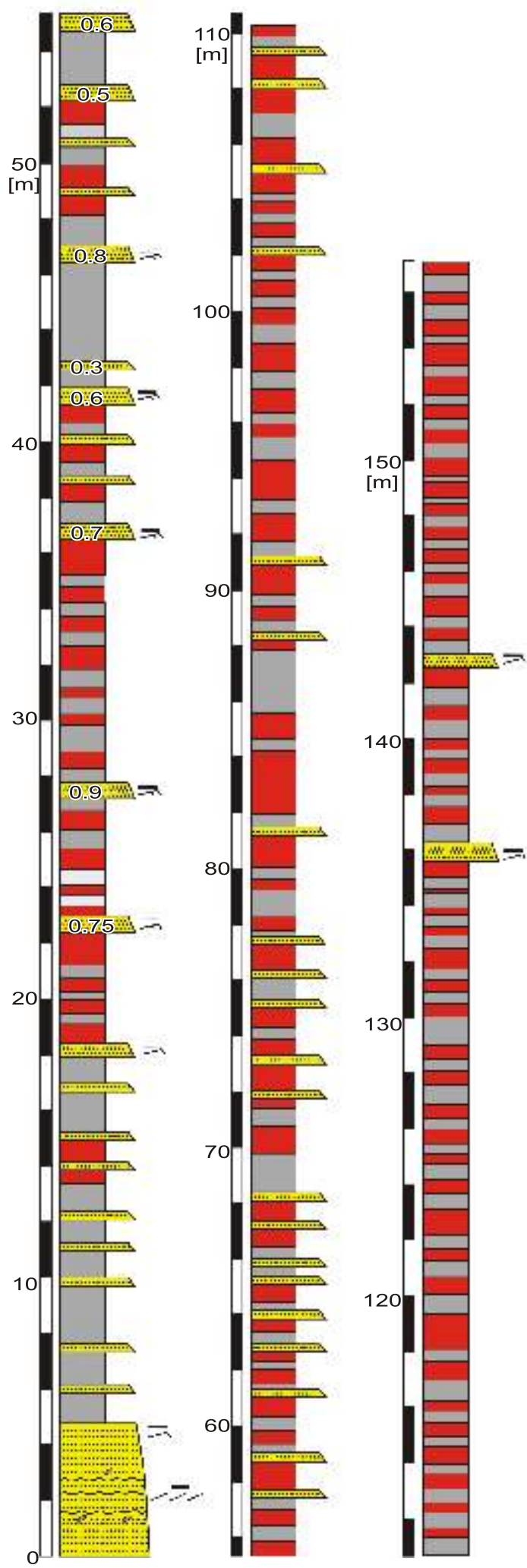

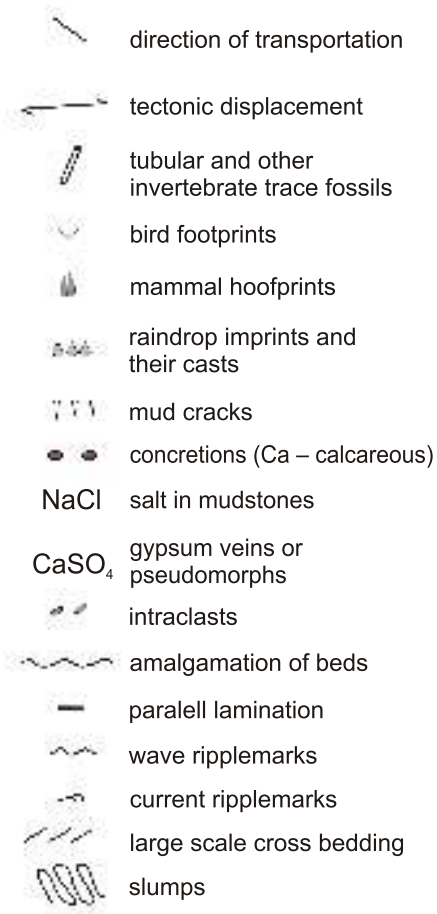

wanc tuffites

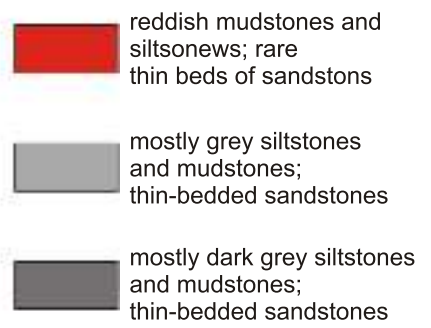

thick and very thick beds :.:.:.:.: of fine- medium- or coarsegrained sandstone

$\because \cdots=$ conglomerate

Fig. 5. Sedimentary log of the lower part of the Stebnyk Formation along the Prut River (section A) and a detailed section of its upper part 

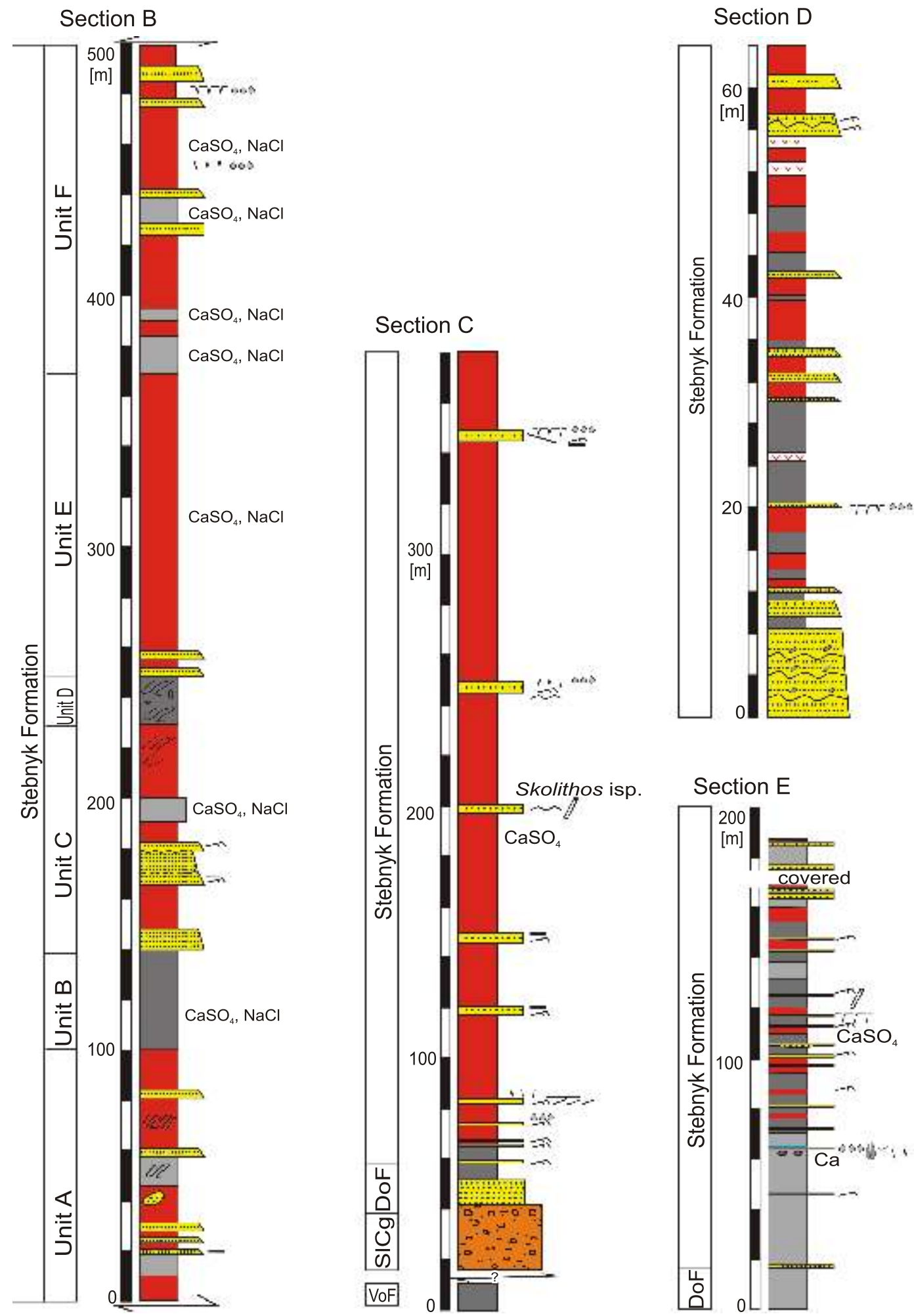

Fig. 6. Sedimentary logs of the Stebnyk Formation in sections B-E

VoF - Vorotyshcha Formation, SICg - Sloboda Conglomerate, DoF - Dobrotiv Formation; for other explanations see Figure 5

the Boryslav-Pokuttya and Sambir nappes. In the Prut River valley, the Stebnyk Formation fills the Dobrotiv Syncline, which is about $3 \mathrm{~km}$ across, located between the Runhur Sloboda Anticline of the Boryslav-Pokuttya Nappe to the south and the Lanchyn Anticline of the Sambir Nappe to the north.
This syncline is clearly asymmetrical and secondarily folded (Fig. 4). On the northern limb of the anticline, the Stebnyk Formation crops out in a ca. $900 \mathrm{~m}$ wide belt (section A). Sedimentary logs of the sections are shown in Figures 5 and 6 , and their facies features in Figures 7-10. 

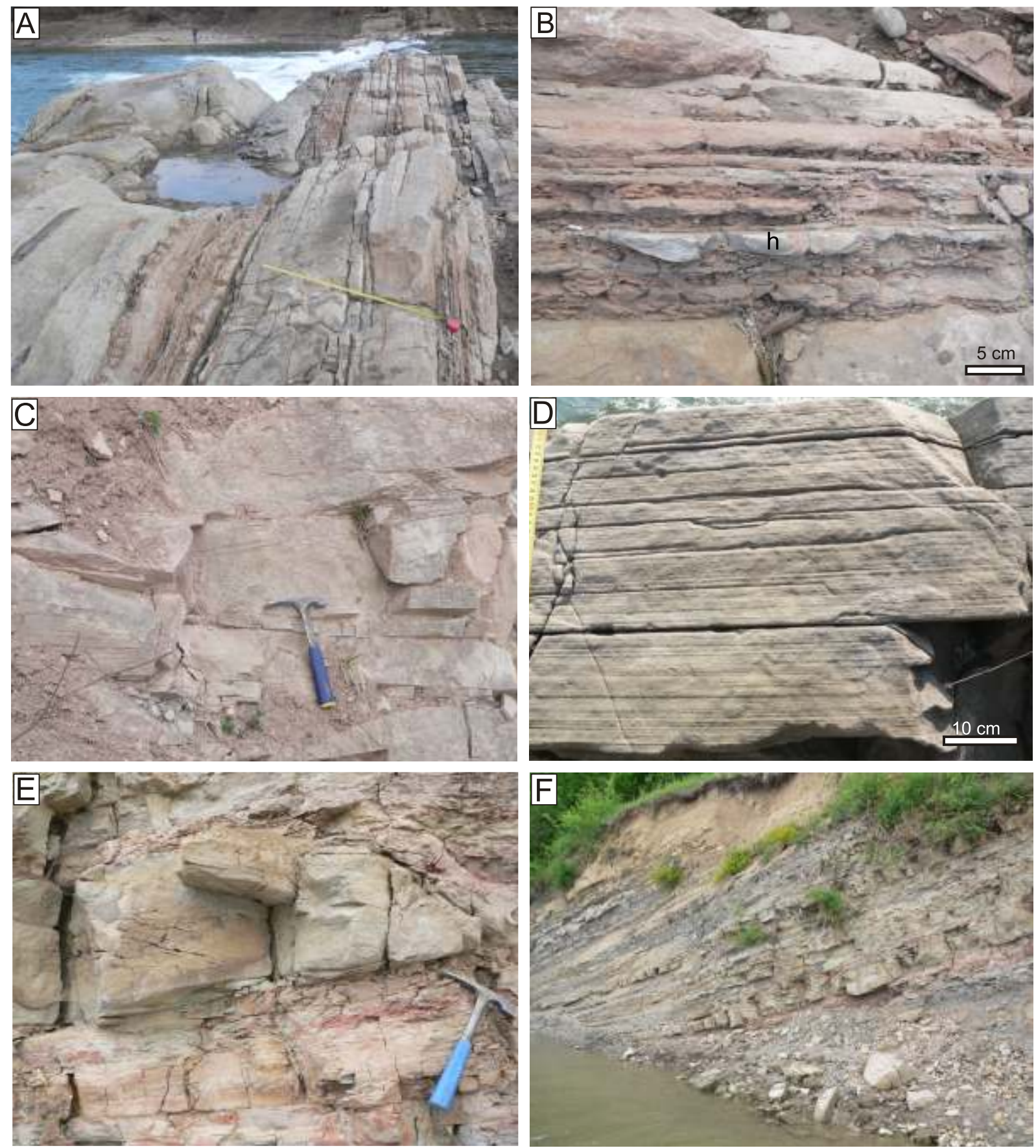

Fig. 7. Facies of the Stebnyk Formation

A - amalgamated thick sandstone beds (channel facies) intercalated with packages of thin sandstone beds and mudstones (levee and crevasse splay facies), section A, the measurement stick is $1 \mathrm{~m}$ long; $\mathbf{B}$ - a package of thin sandstone beds and intercalated mudstones (levee and crevasse splay facies) between thick sandstone beds (channel facies), inverted position, hummocky surface of the bed in the middle $(\mathrm{h})$, section $\mathrm{A} ; \mathrm{C}$ - large-scale cross-bedding in a thick sandstone bed (channel facies), inverted position, section D; D - parallel-laminated thick sandstone bed, section C; E - pinching out, thick, cross-bedded sandstone above variegated mudstones and siltstones, section E; F - thin-bedded sandstones (levee and crevasse facies) intercalated with red, grey and dark grey mudstones, section $\mathrm{E}$

\section{SECTION A}

This section begins at the sedimentary boundary between the Dobrotiv and Stebnyk formations (N48 32 '26.4"; E24 43 09.4") (Oszczypko et al., 2014: fig. 4) and ends on the southern boundary fault of the "Lanchyn Olistostrome" beneath the cable bridge at Dobrotiv (N48³2'38.6'; E2443'51.6”). In the lower part of this formation (Fig. 4), at a distance of $\sim 500 \mathrm{~m}$, beds dip to NE under an angle of $\sim 45^{\circ}$, while in the upper part, at a distance of $\sim 400 \mathrm{~m}$, the beds are rotated to the sub-vertical position and dip to the NW in an overturned position. The hinge of a narrow syncline is located close to the cable bridge at Dobrotiv 

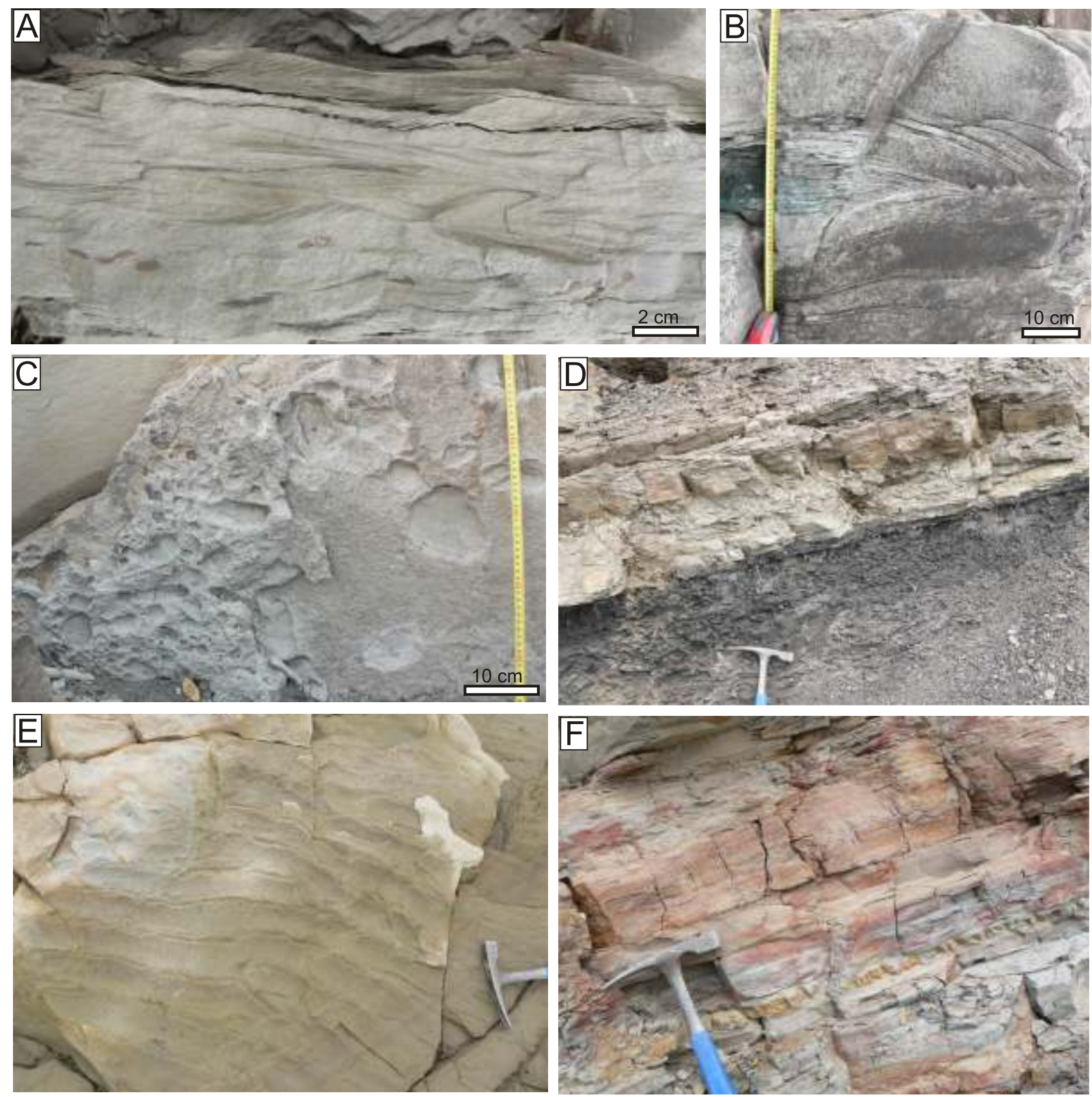

Fig. 8. Some facies features of the Stebnyk Formation

A - cross-rippled lamination in a sandstone bed, with mud intraclasts in the lower part, section E; $\mathbf{B}$ - amalgamated, cross-bedded sandstone, inverted position, section A; C - caverns after mudstone intraclasts in a thick sandstone beds, section A; $\mathbf{D}$ - thin beds of sandstone and siltstone (levee and crevasse splay facies) above dark grey mudstones (organic-rich delta plain facies), section $\mathrm{E} ; \mathbf{E}$ - ripple-marks on the surface of a sandstone bed, section $\mathrm{E} ; \mathbf{F}$ - red and greenish calcareous mudstone and siltstones (delta plain facies), section $\mathrm{E}$

(Figs. 1D and 3). Section A and other sections can be subdivided into units characterized by the same lithological features.

The section (Fig. 5) begins with red-dominated and dark grey mudstones, partly with shale partings (Unit A, $40 \mathrm{~m}$ thick), with a few intercalations of medium- to thick-bedded, cross-laminated sandstone, locally containing the trace fossil Skolithos isp. The inclination of the cross-laminae points to palaeotransport from $260-270^{\circ}$. Higher up, $\sim 180 \mathrm{~m}$ thick red and grey shales prevail (Unit B), with rare intercalations of thin-to medium-bedded sandstone. The next interval, $160 \mathrm{~m}$ thick (Unit C), beginning with a $1.5 \mathrm{~m}$ thick bed of parallel and cross-laminated sandstone (palaeotransport from $270^{\circ}$ ), is composed of thick packages (up to $25 \mathrm{~m}$ thick) of red and grey calcareous mudstones and shales intercalated with five, 1.2-2.0 $\mathrm{m}$ thick sandstone beds, which display large-scale cross- and parallel-bedding (palaeotransport from $270-310^{\circ}$ ). Above, a 90 $\mathrm{m}$ thick succession (Unit $\mathrm{D}$ ) begins with red and grey mudstones and shales followed by a $3 \mathrm{~m}$ thick bed of medium-grained sandstone with parallel and cross-bedding. The latest Unit $\mathrm{E}$ (160 $\mathrm{m}$ thick) begins with a $5 \mathrm{~m}$ thick bed of amalgamated sandstones, intercalated with packages of thin sandstone beds and mudstones (Fig. 7A, B). At the top of the sand- 

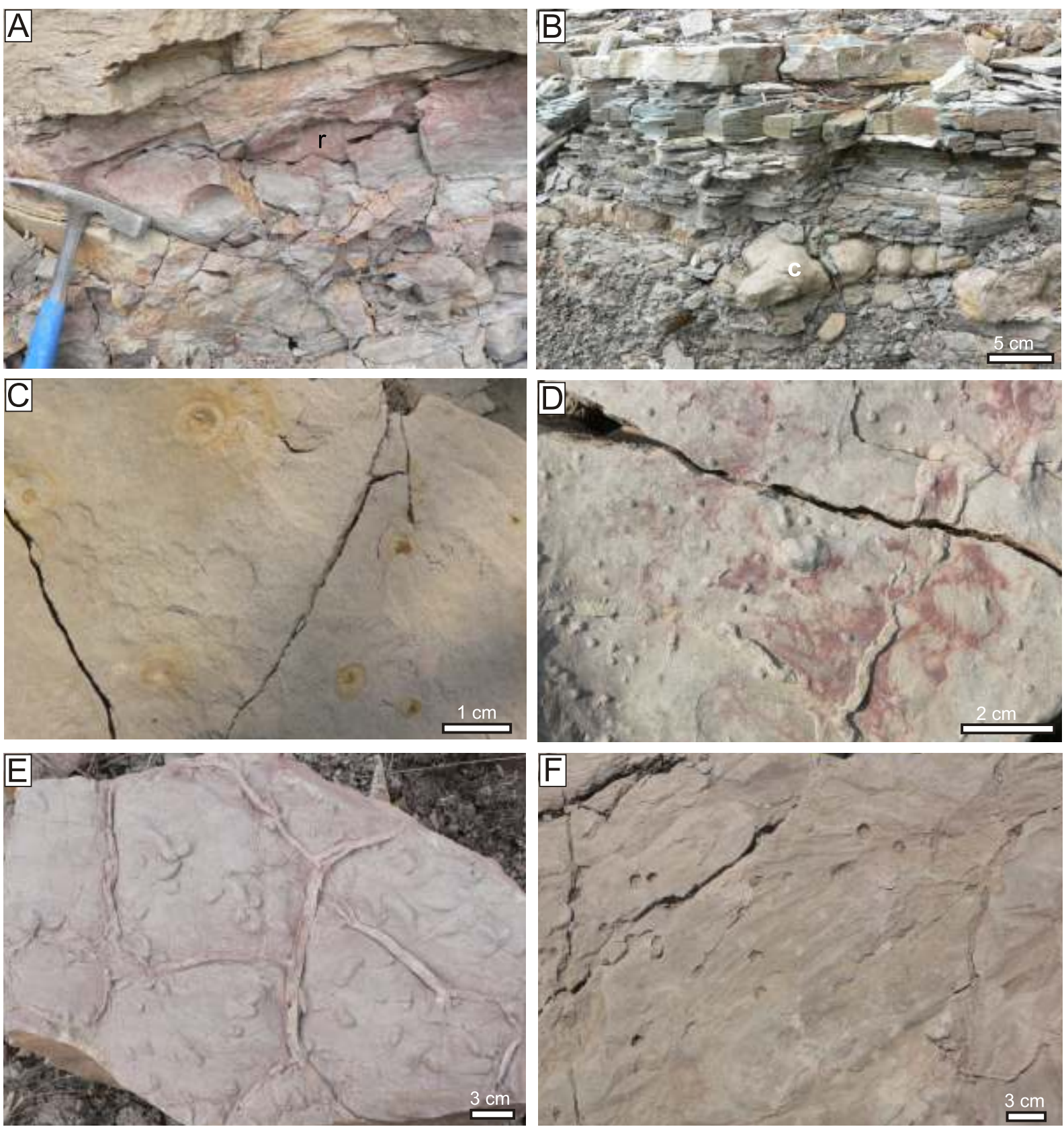

Fig. 9. Some sedimentary, diagenetic and biogenic features of the Stebnyk Formation

A - spotty root structures $(r)$ in red and greenish calcareous mudstone and siltstones (delta plain facies), section E; B - calcareous concretions (c) in intercalations of calcareous mudstones, siltstones and thin-bedded sandstones, section E; $\mathbf{C}$ - ferruginous rings around root structures in a muddy sandstone, section C; D - casts of mudcracks and raindrop imprints, section C; E - lower bedding surface covered by flute casts crossed by mudcracks, section D; F - parting sandstone surface cross-cut by the trace fossil Skolithos isp., section C

stone, we found a level with muddy clasts and mammal footprints. This bed is followed by a succession of red and grey mudstones and shales, with amalgamated, cross-bedded sandstones, in an inverted position (Fig. 8B) and with cavities after mudstone intraclasts in thick sandstone beds (Fig. 8C). The uppermost part of the section A, has been measured "bed by bed" (located between N48 $32^{\prime}$ 31.5"; E244' $40.5^{\prime \prime}$ and N48 32'33.6"; E24 43'46.2") and is shown in Figure 5. The total thickness of the Stebnyk Formation section $\mathrm{A}$ is $\sim 640 \mathrm{~m}$.

\section{SECTION B}

Section B (Figs. 1D and 6) is located between two reverse faults; the northern boundary fault of the "Lanchyn Olistostrome" (N48'32'38.6"; E24 43'51.6") and the other reverse fault (N48³2'54"; E2444'26.9"; Fig. 1D) which separates the west-dipping beds (in overturned position) of the Stebnyk Formation from the east-dipping (normal position) beds of this formation in section C (Fig. 4). Beds of the Stebnyk Formation in 

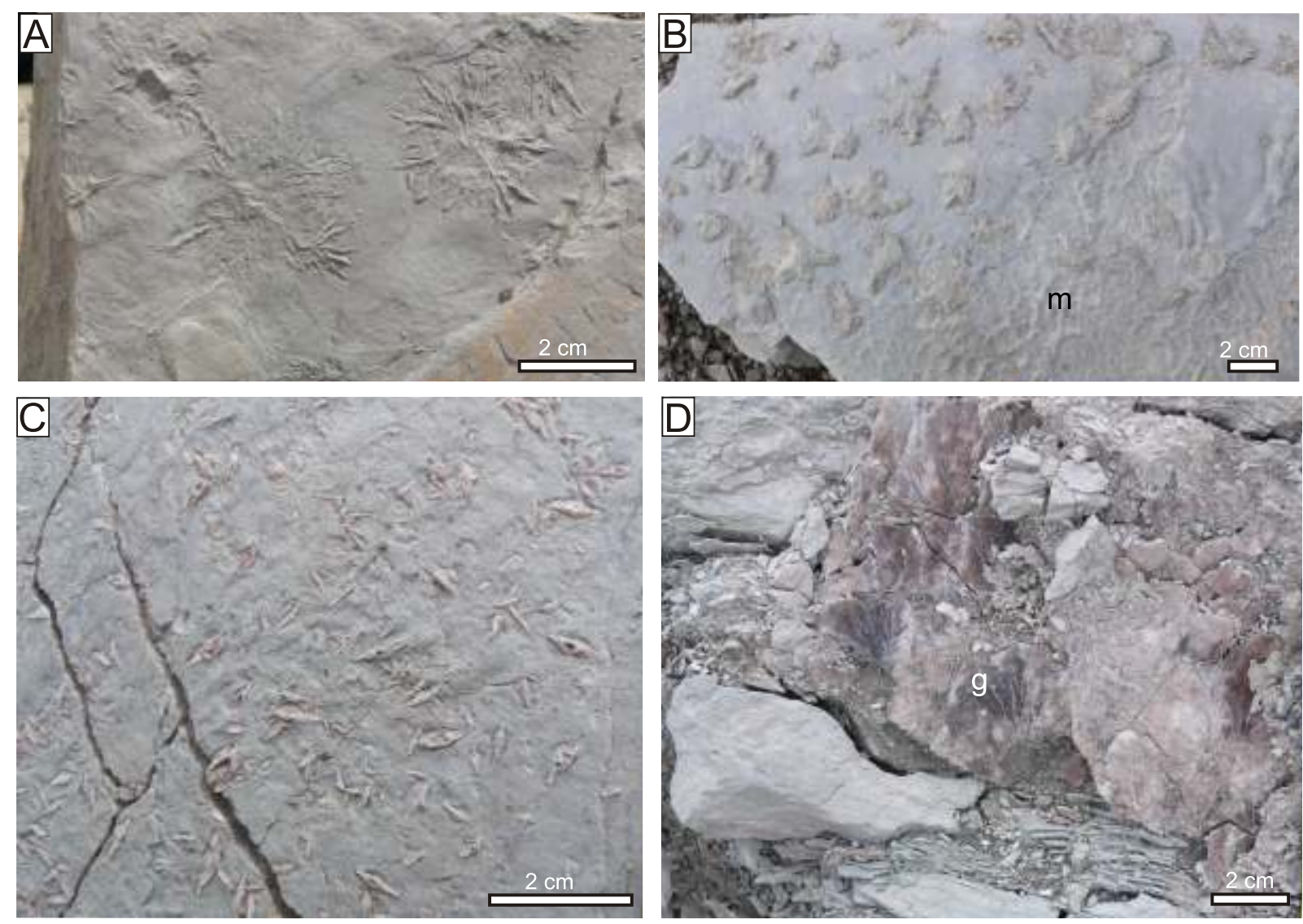

Fig. 10. Some diagenetic and biogenic features of the Stebnyk Formation

A - pseudomorphs after ?gypsum crystals on a sandstone bed surface, section E; B - pseudomorphs after ?gypsum crystals (mainly upper left side) and microbially induced structures $(\mathrm{m})$ on a sandstone bed surface, section B; C - pseudomorphs after ?gypsum crystals on a sandstone bed surface, section B; D - a vein of honey-coloured gypsum (g) in a sandstone and siltstone, section C

section B dip steeply $\left(45-50^{\circ}\right)$ to the west, in an overturned position. The total thickness of the section is up to $500 \mathrm{~m}$.

The first $100 \mathrm{~m}$ thick portion of the section (lower Unit A; Fig. 6), is dominated by red mudstones and shales with crystals of gypsum and salt on parting surfaces (Fig. 10B, C). The mudstones are intercalated with three medium beds of fine-grained sandstone at the base and one thick bed of muscovitic sandstone at the top of Unit A. This unit contains also two disturbed beds, up to $10 \mathrm{~m}$ thick, with blocks of sandstone (Fig. 11C) and gypsum in fissures. The next $40 \mathrm{~m}$ thick portion (Unit B) is composed of dark grey mudstones. The mudstones are intercalated with two beds (up to 0.5 thick each) of fine- to medium-grained sandstone. The upper $10 \mathrm{~m}$ thick part of this portion is composed of laminated mudstone with intercalations of four, medium-bedded, parallel-laminated and amalgamated sandstone beds (Fig. 7D). This unit is followed by $85 \mathrm{~m}$ of red shales (Unit C) with two beds of amalgamated, fine-grained, thick-bedded sandstone, with fissures filled with pink and honey-coloured gypsum (Fig. 10D). The next portion (Unit $\mathrm{D}$ ) is $20 \mathrm{~m}$ thick and composed of dark grey mudflow deposits with gypsum. The higher Unit E $(120 \mathrm{~m}$ thick) is composed of red mudstones with thin intercalations of fine-grained sandstone with dispersed salt and gypsum crystals. The section B is terminated by ca. $130 \mathrm{~m}$ thick succession (Unit F) of red and dark grey mudstone with mudcracks and rain prints (Fig. 9D) followed by two thick-bedded $(\sim 50 \mathrm{~cm})$ sandstones. The total thickness of the section B attains $500 \mathrm{~m}$.

\section{SECTION C}

Section $\mathrm{C}$ is followed along the river for $1.2 \mathrm{~km}$. It begins from the footbridge across the Prut River at Lanchyn (N48 $33^{\prime} 01.5^{\prime \prime}$; E24 $\left.45^{\prime} 15.5^{\prime \prime}\right)$ and it continues up to a reverse fault (N48'32'54"; E24⒋'26.9') separating sections C and B. The section, $320 \mathrm{~m}$ thick, is built of gently folded beds of the Stebnyk Formation in a normal position (Fig. 4). According to Oszczypko et al. (2014), this section is located in the southern limb of the Lanchyn Anticline, with a transition from the uppermost part of the Vorotyshcha Formation through the Sloboda Conglomerate and the Dobrotiv Formation, strongly reduced in thickness, followed by the lower part of the Stebnyk (Fig. 6) of the Sambir Nappe.

In this section, the Stebnyk Formation is composed of variegated mudstones, red and dark grey, with a predominance of red mudstones. The variegated mudstones are intercalated with medium-bedded, cross-laminated sandstones $(20-30 \mathrm{~cm}$ thick), which indicate palaeotransport from the north-west. Sporadically, in the upper and lower part of the section, thick beds of 

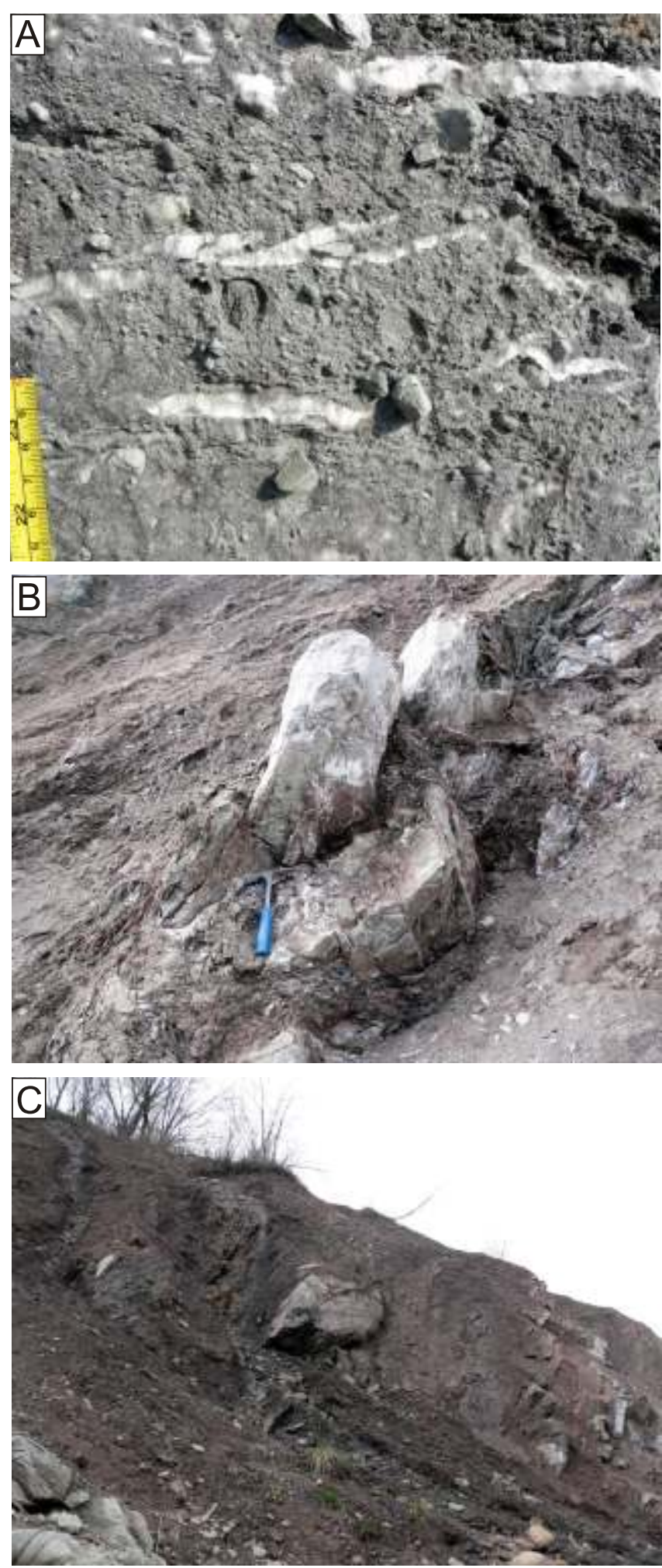

Fig. 11. Sedimentary features of the diapir at Lanchyn

A - grey mudstones with lenses of gypsum, Vorotyshcha Formation; B - deformed, partly imbricated fragments of a thick sandstone bed, Stebnyk Formation, side of the structure; $\mathbf{C}$ - an isolated block of sandstone within deformed strata of the Stebnyk Formation fine-to medium-grained, parallel- to cross-bedded sandstone occur (Fig. 7D). The cross-bedding indicates palaeoflow from the north-west. Thinner, muddy sandstone beds show mudcracks and raindrop imprints and rarely ferruginous rings around root structures (Fig. 9C).

\section{SECTION D}

Deposits of section $\mathrm{D}$ are visible in a large exposure over a distance of $\sim 1300 \mathrm{~m}$ in cliffs up to $\sim 100 \mathrm{~m}$ high along the left bank of the Bystrytsia Nadvirnanska River at Nadvirna (Fig. 3B;

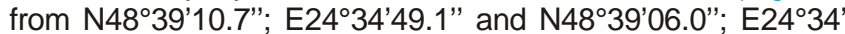
$\left.21.5^{\prime \prime}\right)$. Beds dip to the north are overturned (antiformal syncline, see Vialov, 1965). The exposure probably represents the middle part (rich in thick-bedded sandstones) of the Stebnyk Formation of the Boryslav-Pokuttya Nappe. The measured part of the exposure (ca. $64 \mathrm{~m}$ thick) is located in its topographically lower part, which was stratigraphically measurable in the upper (younger) part of the succession (Fig. 3B).

After rotation of the measured section to the normal position, the section begins with amalgamated, very thick-bedded (10.2 m) sandstone (N48`39'07.2”; E24³4'29.2”, 429 m a.s.I.), which is overlain by two sandstone beds (1.2 and $0.6 \mathrm{~m}$ thick), followed by $\sim 9 \mathrm{~m}$ thick package of red and grey mudstones and shales, with a $30 \mathrm{~cm}$ thick sandstone bed at the top (Fig. 6). The next interval, $10 \mathrm{~m}$ thick, is composed of variegated mudstones with an intercalation of bright, $17 \mathrm{~cm}$ thick tuffite, which is covered by a $60 \mathrm{~cm}$ thick sandstone bed at the top. Stratigraphically above are variegated mudstones, $1.8 \mathrm{~m}$ thick, with a $60 \mathrm{~cm}$ thick, fine- to medium-grained sandstone at the top, followed by the next variegated mudstone package, $10.8 \mathrm{~m}$ thick, overlain by a $40 \mathrm{~cm}$ thick sandstone bed. Higher up, a $10 \mathrm{~m}$ thick portion of the section is composed of red-brick and grey-greenish mudstones with intercalations of thin-bedded sandstone (1-2 cm thick; Fig. $9 \mathrm{E})$. Above, $\sim 5 \mathrm{~m}$ of variegated mudstones with three tuffite layers, respectively $3.5 \mathrm{~cm}, 9 \mathrm{~cm}$ (both rose in colour), and $11 \mathrm{~cm}$ (grey-greenish) thick are present (N48³9'06.9”; E24³4'26.0”'). This tuffite-bearing part is overlain by an amalgamated sandstone bed, which is $5 \mathrm{~m}$ thick (N48³9'07.0"; E2434'34.0'). The measured part of the section is terminated by a $40 \mathrm{~cm}$ thick, cross-bedded sandstone bed with a wavy top. Another $5 \mathrm{~m}$ thick sandstone bed occurs in the northern part of the exposure (N48³9'08.5"; E24³4'38.0").

\section{SECTION E}

Section E is located in the southern limb of the Runhury Sloboda Anticline (Boryslav-Pokuttya Nappe; Fig. 1D), along the Prut River, near Zariche (GPS coordinates: from N48 $32.074^{\prime \prime}$; E2440.030" to N48³2.004"; E2439.256”). This section is representative of the transition from the uppermost part of the Dobrotiv Formation to the Stebnyk Formation (Fig. 6; see also Oszczypko et al., 2014).

Section $E$ begins with a $\sim 42$ m thick unit of grey siltstones and mudstones with sporadic intercalations of thin bedded sandstone (Figs. 6 and 8A). The top of this unit displays grey siltstones with calcareous concretions and thin-bedded sandstones with mud cracks, raindrop imprints, root structures (Fig. 9A) and concretions (Fig. 9B). The next interval, 50 m thick, is dominated by grey, dark grey and reddish mudstones with very rare intercalations of thin-bedded sandstone (Figs. 7E, F 
and 8D), some with ripple marks (Fig. 8E). Above, grey, dark grey and red mudstones, $\sim 30 \mathrm{~m}$ thick, are exposed. The last interval ( 30 m thick) displays grey and reddish mudstones with thick-bedded sandstones at the top, The Stebnyk Formation is at least $170 \mathrm{~m}$ thick in section $\mathrm{E}$.

\section{LITHOFACIES}

The Stebnyk Formation displays characteristic lithofacies, which are characterized by a certain set of sedimentary features (Figs. 5-10). They allow interpretation of their respective depositional palaeoenvironments.

Thick-, medium- to thin-bedded sandstones (Figs. 7A, $\mathrm{C}-\mathrm{E}$ and $8 \mathrm{~B}$ ). The sandstones are fine- to coarse-grained. Some beds are rich in muddy matrix. The thick beds can display large-scale cross-bedding or horizontal lamination. Cross-laminated sets can be separated by amalgamation surfaces. In thinner beds, ripple-lamination is common. Some beds are rich in mud intraclasts (Fig. 8C). This facies form packages, which start with the thickest sandstone bed. Above, thinner sandstone beds intercalated with mudstones and siltstones, usually rose in colour, are present. The packages are from 0.5 to $5 \mathrm{~m}$ thick. Many beds of all thicknesses change their thickness and pinch out. The thinner beds can display mudcracks. Surfaces of some beds display variable pseudomorphs after gypsum crystals (Fig. 10A-C). Many fissures crossing sandstone beds and mudstones in all facies are filled with gypsum (Fig. 10D).

Thin- and medium-bedded sandstones (Figs. 7B, F and $8 A, D, F)$. The sandstones are fine- to medium-grained, ripple-laminated, rarely horizontally or sub-horizontally laminated, usually with sharp bases and gradational tops, centimetre- to decimetre-thick. Rarely, flute casts can be observed at their base, showing unidirectional, erosional flow (Fig. 9E). The sandstone beds are tabular or pinch out on the scale of exposures (up to a few, or a few tens of metres); some may display hummocky tops (Fig. 7B). Some of the beds display mudcracks (Fig. 9D, E), raindrop imprints and imprint casts (Fig. 9D), mud intraclasts, ripple-marks (Fig. 8E). Locally, root structures can be marked by ferruginized haloes (Fig. 9C). This facies corresponds to the Nadvirna type distinguished by Cizancourt (1925).

Variegated mudstones and siltstones (Figs. 8F and 9A, B). Bedded, rose, reddish, greenish or light grey variegated marly mudstones are the most eye-catching, dominant and basic lithology, present through the whole section of the Stebnyk Formation. Intercalations of siltstone showing the same colours and other features are less common. Most of the mudstone is rose, with gradual transition to other colours. Locally, diffuse enclaves of some colours form spots against a background of other colours. Some of these can be interpreted as root structures (Fig. 9A). At some horizons calcareous concretions are present (Fig. 9B). The rose mudstones can form about $10 \mathrm{~m}$ thick packages intercalated with packages a few metres thick of light grey or greenish mudstones (e.g., lower part of section A). Centimetre- to decimetre-thick bedding is locally easily visible, locally marked by subtle changes of grain size. Pinching out of siltstone beds is locally present. In some beds, horizontal lamination is easily visible, but in others the mudstones seem to massive. The lamination is parallel or subparallel, and locally can be disturbed plastically or interrupted by bioturbational structures. The content of calcium carbonate fluctuates, some mudstones being calcare- ous locally with transitions to marls. Locally, small crystals of gypsum or their pseudomorphs can be observed. This facies contains intercalations of variable sandstones or dark grey mudstones, which are ascribed to other lithofacies. This facies corresponds to the Strutyn type distinguished by Cizancourt (1925).

Dark grey mudstones (Figs. 7F and 8D). Dark grey calcareous mudstones are rare, though locally present as packages up to a few metres thick sandwiched between the variegated mudstones and siltstones. They are mostly massive and can be intercalated with thin- to medium-grained muddy sandstones.

\section{DISCUSSION}

\section{THE "LANCHYN OLISTOSTROME" - A DIAPIR FOLD OR A TECTONIC WINDOW?}

According to Hnylko et al. (2012, 2014; see also Hnylko, 2001), the Stebnyk Formation of the Boryslav-Pokuttya Nappe (Outer Carpathians) in the Prut River contacts with the Lanchyn Olistostrome of the Sambir Nappe (Carpathian Foredeep). In this interpretation, the Lanchyn Olistostrome, up to $1 \mathrm{~km}$ thick, composed of the Stebnyk Formation deposits, is incorporated into the Balych Formation (Badenian) of the Sambir Nappe.

Based on our field observations, a re-interpretation of the "chaotic" deposits ascribed to the "Lanchyn Olistostrome" between Lanchyn and Dobrotiv is proposed, as follows:

1. The deposits regarded by Hnylko $(2010,2012,2014)$ as the "Lanchyn Olistostrome" are located in the Prut River, between the studied sections A and B of the Stebnyk Formation (Figs. 1D and 4). The southern boundary between the "chaotic deposits" and section A is located along the left river bank, ca. $50 \mathrm{~m}$ beneath the Dobrotiv cable bridge, where sub-vertical SW-dipping, strongly brecciated, dark grey salt clays (Fig. 11A) with gypsum as well as blocks of "Sloboda-type" conglomerate and thick-bedded sandstones, associated with rose marly mudstones of the Stebnyk Formation, are exposed (Fig. 11B, C). Such "chaotic" deposits, 350-400 m thick, can be traced downriver for a distance of about $500 \mathrm{~m}$. These deposits also contact with the Stebnyk Formation of section $B$ along a reverse fault. The same deposits were observed on the right river bank, beneath the cable bridge (Fig. 4). In this case, the salt clay breccia of Vorotyshcha type, incorporated into the folded deposits of the Stebnyk Formation, reached only $15 \mathrm{~m}$ in thickness.

2. The salt clay breccia described was considered previously as the Vorotyshcha Olistostrome (Andreyeva-Grigorovich et al., 2008a). The "Lanchyn Olistostrome" does not occur within the Balych Formation, but is overlain by the Stebnyk Formation.

3. It is difficult to explain how the Lanchyn olistostrome has been developed in such relatively shallow-water or even continental (alluvial plain; see the next chapter) deposits of the Stebnyk Formation environment.

4. For a proper interpretation of the chaotic deposits of the "Lanchyn Olistostrome" in the section studied, the following points may be considered:

a - the tripartite division of the Vorotyshcha Formation includes the upper and lower salt clays, separated by Sloboda-type conglomerates (Vialov, 1965; Gurzhyi, 1969; Andreyeva-Grigorovich et al., 1997). Such an association of salt clays and conglomerates is nothing strange; 
b - in the study area, the distribution of the Sloboda Conglomerate and the Dobrotiv Formation is discontinuous (e.g., in the Lanchyn section) and the salt clays with gypsum of the Vorotyshcha Formation can occur directly under the Stebnyk Formation;

c - in several sections of the region studied, Tołwiński (1950) described vertical, direct, tectonic contacts of salt clays (Vorotyshcha Formation) with pink marls of the Stebnyk Formation (e.g., in the Runhury Sloboda and Jabloniv anticlines); Swiderski (1925) concluded that the salt clays come out from under the Stebnyk Formation (his red shales and sandstones);

$\mathrm{d}$ - the above-mentioned data clearly suggest that this structure could be a salt-clay diapir fold, accompanied by salt brine springs, among others at Lanchyn and at nearby Vy hny Maydan and Molodiatyn (Bujalski, 1938; Tołwiński, 1950).

5. Summarizing, we find that the "Lanchyn Olistostrome" (Figs. 1D, 3 and 4) located near the Dobrotiv cable bridge, may be a diapir built of the Vorotyshcha Formation, which pierces the Stebnyk Formation in the southern limb of the Lanchyn Anticline.

6. The tectonic origin of the "Lanchyn Olistostrome" is also suggested by its contacts with overturned deposits of the Stebnyk Formation in sections $A$ and $B$. In our opinion, this "olistostrome" displays features of a "flower structure" kind composed of tectonically deformed deposits, but it does not display any feature of a synsedimentary olistostrome.

7. Another possible explanation is that this is a tectonic window of the salt deposits of the Stebnyk Formation of the Sambir Nappe, nevertheless of a diapir character.

8. We do not question the presence of olistostrome deposits outside of the study area.

\section{DEPOSITIONAL SYSTEM AND ENVIRONMENT}

The depositional environment of the Stebnyk Formation remains poorly determined. Tołwiński (1950) regarded that the succession of the Dobrotiv and the Stebnyk formations reflects deposition in a deepening basin with increasing distance from the shore. Vialov (1960) suggested that the environment of the Stebnyk Formation was characterized by wide beaches and very shallow water, with frequent migrations of the shoreline, but Tkachenko (1961) postulated a fully marine environment referred to a transgression, and partial restriction of the basin during sedimentation of the middle part of the formation. Vialov (1965) noted that the presence of tetrapod footprints, mudcracks and raindrop imprints demonstrates subaerial conditions at some horizons. Głowacki et al. (1966) suggested a lagoonal environment for the salt-bearing formations of the region, and Gurzhyi (1969) proposed the same environment for the Stebnyk Formation and stated that its clastic material derived from flat and hilly shores. Vialov et al. (1981) regarded conglomerates of the Stebnyk Formation as a marginal facies, which transit to sandstone and mudstone facies towards the inner parts of the basin. The presence of marine foraminifers and calcareous nannoplankton, at least in the upper part of the formation (see previous work) shows marine influence, though the common occurrence of tetrapod footprints, mudcracks and raindrop imprints, the absence of marine macro- and microfossils in most of the deposits, and the overall "red beds" character of the Stebnyk Formation challenges the suggestion of a prevailing marine environment, including a lagoonal environment, for which conglomerates are atypical sediments (e.g.,
Einsele, 2000). Kulchytsky and Kulchytsky (1980) who reported tetrapod footprints at levels located 20-30 m, 100-150 m and 280-340 m above the base of the formation in the Deliatyn area, concluded that the deposition of the Dobrotiv and Stebnyk formations took place in a changeable shallow-water basin with many shoals, barriers and islands, and that the basin was surrounded by an alluvial plain with plants and animals typical of a dry savannah. Khrushchov and Kompanets (1988) distinguished four facies in the Stebnyk Formation:

- deltaic facies, which are mostly sandy;

- near-shore facies - mostly mudstones and sandstones,

- shallow-marine facies - mostly mudstones and sandstones;

- marine deposits - mostly mudstones and sandstones with erosive bases.

Following their descriptions, the first facies was not found in the sections studied. The interpretations of facies 2-4 cannot be accepted. The authors cited found raindrop imprints and mudcracks in them, and their sedimentary features are different from standard nearshore and shallow-marine facies (e.g., Einsele, 2000).

Considerations regarding the palaeoenvironment of the deposits studied should include the context of the whole Stebnyk Formation, which represents a large depositional system in a certain geotectonic setting of the Carpathian Foredeep. In the Ukrainian Carpathians, the formation occurs in a narrow belt. Gagała et al. (2012) estimated the width of the "Stebnyk Basin" at about $70 \mathrm{~km}$ at the meridian of Przemyśl. Very likely, this width reached up to $100 \mathrm{~km}$ some tens of kilometres to the east, but it is unclear whether the Stebnyk Formation occupied the whole width of the basin represented by the Boryslav-Pokuttya and the Sambir nappes. The belt of the Stebnyk Formation stretches along the Carpathian front from SE Poland to at least the Ukrainian-Romanian border, for at least $300 \mathrm{~km}$ (Fig. 12). Ney (1968) and Ney et al. (1974) postulated deposition of the Stebnyk Formation in the gutter-like basin developed in front of the overthrusting Carpathian orogen. According to the literature (e.g., Vialov, 1965; Gurzhyi, 1969; Ney et al., 1974), the belt of Stebnyk Formation is characterized by a distinct polarity of facies, with a high contribution of conglomerates and thick-bedded sandstones, especially in the lower part of the formation, disappearance of conglomerates and fining of the succession further to the SE, which is seen very well in the study area. A reduction in general thickness of the formation to the SE is also possible; it attains $1200 \mathrm{~m}$ in SE Poland (Ney et al., 1974), and locally $2000 \mathrm{~m}$ in the western part of Ukraine (Gurzhyi, 1969), and $600 \mathrm{~m}$ in section $\mathrm{A}$ (this study). The formation was deposited over 1.2 m.y. (Andreyeva-Grigorovich et al., 2008a). This gives a very high accumulation rate of $50-167 \mathrm{~cm} / \mathrm{Ky}$. Most of the thicker sandstone beds in the study area show erosive bases and include intraclasts and cross-bedding. The sand was transported by water flowing from the west and north-west as shown by inclination of cross-laminae in several beds of the sections studied and by the orientation of flute casts in some beds. No evidence of wave action or tides was observed. The conglomerates of the formation (western part) contain material from the foreland (mostly phyllites) and from the Carpathian flysch. Coarse-grained sandstones contains many lithic grains that indicate short transport (Gurzhyi, 1969).

All these data suggest that the depositional system (or a system tract) was transported mostly from the west and northwest, with clastic material deriving from the rising Carpathian orogenic belt and from the foreland forebulge, which confined the depositional belt of the Stebnyk Formation from both sides. The conglomerates might have been deposited as alluvial fans 


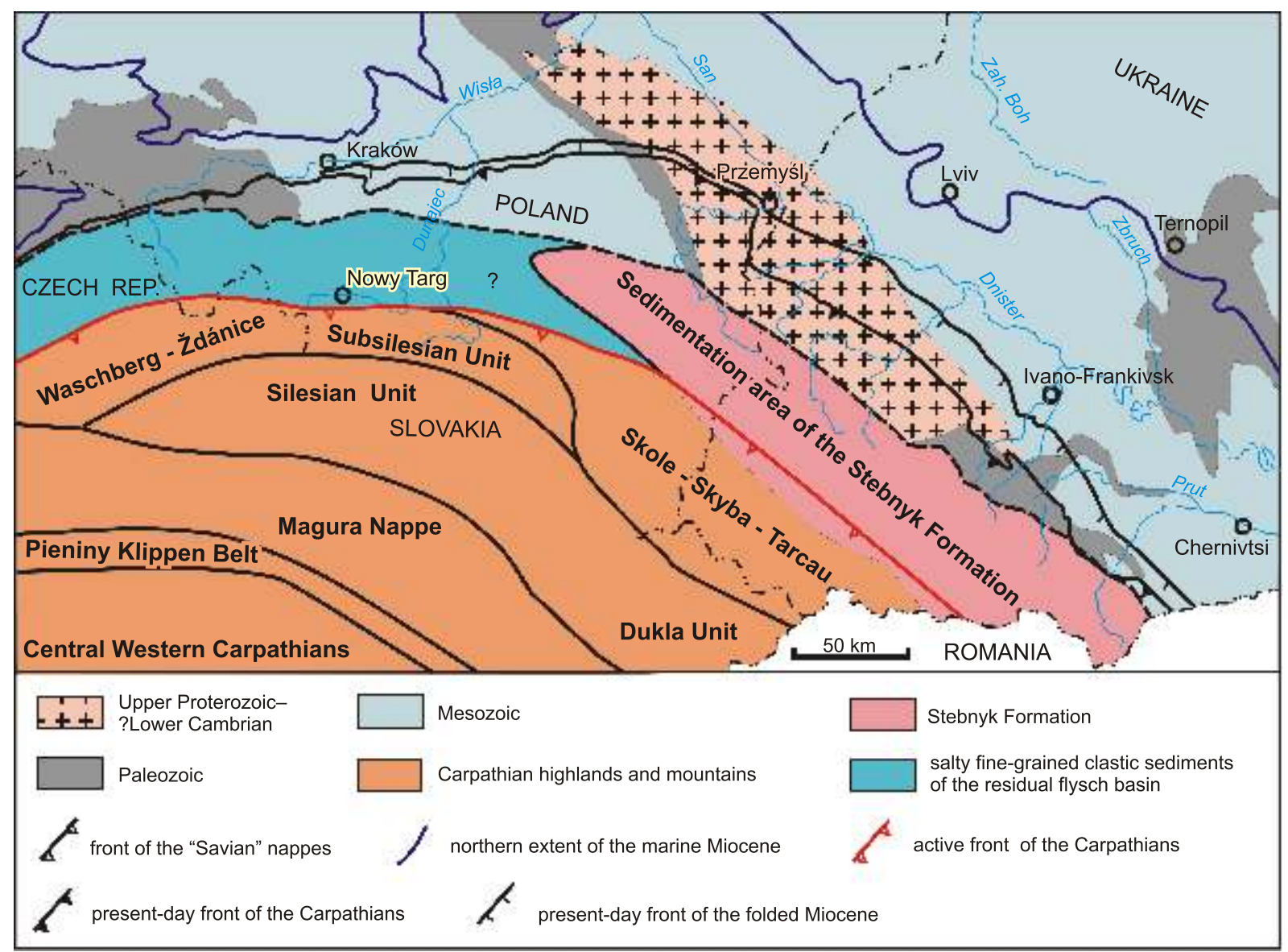

Fig. 12. Palaeogeographic scheme of the Karpatian-Early Badenian in the study region (based on Oszczypko and Oszczypko-Clowes, 2003; Oszczypko et al., 2006, 2012, supplemented)

and fan-deltas, as for the older Sloboda Conglomerate in the study area (see Oszczypko et al., 2012), or in braided rivers. Further to the south-east, as in the study area, the system became more distal with a transition to a delta plain, which was cross-cut by river channels. In migrating channels, the thicker sandstone beds were deposited. The thinner sandstone beds can be related to channel levees and crevasse splays. The basic facies, i.e. the red mudstones, were deposited on the delta plain. Marine ingressions to the delta plain took place as the upper part of the formation was deposited (as indicated by Miocene marine microfossils), which is overlain and partly laterally replaced by the marine Balych Formation, but no clear sedimentary features of marine sedimentation have been encountered in the Stebnyk Formation. Vialov (1966) considered that the presence of Skolithos is some exposures of the Stebnyk Formation is evidence of a marine environment, but this trace fossil is known also from fluvial settings (e.g., Buatois and Mángano, 2007).

The weak part of this interpretation is the absence of delta front deposits, with typical thickening-up packages and large-scale cross-bedding with foreset units. These may be farther to the south-east or in the overlying Balych Formation, but no investigations have been made that could prove or disprove this hypothesis. Maybe the sandstone-dominated deltaic facies in 0.5-16 $\mathrm{m}$ thick packages distinguished by Khrushchov and Kompanets (1988) indeed represent a delta front facies, but they were not found in the sections studied. It is also possible that delta front deposits were not developed, as in the underlying Dobrotiv Formation interpreted as a mud-dominated depositional system (see Oszczypko et al., 2014). This is a feature of type $\mathrm{C}$ shallow-water deltas dominated by fluvial processes, where the very shallow water in the water basin does not allow development of typical mouth bars; instead, gently inclined (a few degrees) beds are deposited (Postma, 1990). Such beds are difficult to recognize even if they are traced for several tens of metres, as in the scale of most exposures in the study area. Also deltaic sediments that accumulated in shallow lakes, with very limited accommodation space, do not form typical thickening-up packages of beds (Tye and Coleman, 1989). General fining of the succession up the Stebnyk Formation, which is very clear in SE Poland (Ney et al., 1974) and the transition to the marine Balych Formation show an overall retrogradation of the depositional system.

That a high rate of accumulation was compensated by subsidence had already been noticed by Tołwiński (1950). Flexural modelling of the Polish and Ukrainian Carpathian orogen (Royden and Burchfiel, 1989; Krzywiec and Jochym, 1997) suggests that deeper crustal processes and associated subsurface loads are responsible for the present-day flexural bending of the foreland lithospheric plate (see also Kováč et al., 1998; Oszczypko et al., 2006 and references therein). During the Ottnangian-Karpatian, the rate of subsidence at the 
front of the Ukrainian Outer Carpathians may have reached at least 2000 m/m.y. (Oszczypko, 1998) and it was compensated by sediment input, including of those belonging to the Stebnyk Formation.

Onset of coarser sedimentation of the lower part of the Stebnyk Formation, especially in the north-west of its depositional area, may have been caused by a lowering of the base level. An about $30 \mathrm{~m}$ drop in sea level around the Burdigalian-Langhian boundary, before the Middle Miocene Climatic Optimum, has been postulated (Hilgen et al., 2012). However, some geotectonic processes in the foredeep development may have been the dominant factor, such as the intra-Burdigalian folding and uplift of the Outer Carpathians related to the north-eastwards translation of the Alcapa and Tisza-Dacia microplates, in response to the roll-back of the Carpathian subduction slab (Zoetemeijer et al., 1999; Ziegler et al., 2002; Rasser et al., 2008).

\section{PALAEOCLIMATIC ASPECTS}

The red bed character of the deposits of the Stebnyk Formation, the presence of evaporitic minerals and the common mudcracks suggest frequent drying of the sediment surface and generally a hot climate favouring evaporation. The deposits of zones NN4-NN5 (sedimentation of the Stebnyk Formation corresponds to the upper part of the NN4 - lower part of the NN5 zones; Fig. 2) show evaporitic facies only in the eastern part of the Carpathian Foredeep, not in its western part or in the Central Paratethys (see Kováč et al., 2003). Such conditions show a climatic change with respect to the underlying Dobrotiv Formation, the deposits of which are generally grey, with no mudcracks even in horizons with tetrapod footprints (Oszczypko et al., 2014), except for the uppermost part of the formation, where Vialov (1965) noted some mudcracks. This change corresponds well to the global trend, but with some regional differences. Generally, the interval between 17 and $15 \mathrm{Ma}$ (16.5-14 Ma - uppermost Karpatian-Early Badenian sedimentation of the Stebnyk and the Balych formations; see Andreyeva-Grigorovich et al., 2008a; Fig. 2) is referred to the Middle Miocene Climatic Optimum characterized by global warmth, a high content of $\mathrm{CO}_{2}$ in the atmosphere, and a significant decrease in the size of the Antarctic icecap (Foster et al., 2012). Kroh (2007) studied Miocene echinoids and associated echinoderm faunas from the Paratethys in the context of the climate. He concluded that the temperature rose from the Karpatian to the Early Badenian optimum up to tropical levels (sea surface temperatures $16-17^{\circ} \mathrm{C}$ during winter and up $28^{\circ} \mathrm{C}$ during summer) for the Central Paratethys; however, he suggested that the Carpathian Foredeep part still remained in the temperate climate zone, with the reservation that the faunal differences between these regions may have been influenced by isolation. Taking in account that the deposits of the Stebnyk Formation and coeval strata are not suitable for de- velopment of such fauna due to continental or hypersaline conditions, the increase in the temperature noted probably touched also the eastern part of the Carpathian Foredeep and influenced sedimentation of the Stebnyk Formation. Lower temperatures obtained on the basis of oxygen isotopes from bryozoan skeletons, mainly for the Vienna Basin and the western part of the Carpathian Foredeep, and related to upwelling (Key et al., 2013) may rather reflect local conditions. Continuous Late Paleogene-Neogene aridification of the climate, known from the Eurasian interior and from the Northern Hemisphere in general, was related to global cooling and its consequences (Tang and Ding, 2013). However, this trend varied locally in space and time (Eronen et al., 2012). For instance, coeval sections from Bulgaria, located roughly $500 \mathrm{~km}$ to south-east from the study area, do not show any palaeobotanical evidence of arid climate (Ivanov et al., 2012). However, it cannot be excluded that the climate of the eastern part of the Carpathian Foredeep, by its location, was more influenced by this aridification than in the other parts of the Paratethys.

\section{CONCLUSIONS}

The Miocene Stebnyk Formation (Karpatian-Middle Badenian) is a 600-2000 m thick unit of the Boryslav-Pokuttya and Sambir nappes. It contains conglomerates and thick-bedded sandstones in the lower part in the north-west. In the upper part and in the entire section further to the south-east, it is dominated by variegated calcareous mudstones and siltstones intercalated with sandstones as in the study area in the valley of the Prut River, between Deliatyn and Lanchyn. These deposits represent mostly a delta plain facies, where mudstones were deposited in the interchannel areas, thick sandstone beds in the distributary channels and thinner sandstone beds in channel levees and crevasse splays. In the upper part of the formation, marine ingressions are marked by an occurrence of marine microfossils (NN4 and locally NN5 zones). Sediments of the Stebnyk Formation accumulated at rates of $50-167 \mathrm{~cm} / \mathrm{kyr}$ in a narrow and long (at least $300 \mathrm{~km}$ ) depression between the rising Carpathian orogen and the forebulge elevation of the European Platform foreland, in warm and semi-dry climatic conditions ( Middle Miocene Climatic Optimum). The accumulation was compensated by subsidence in the developing Carpathian Foredeep. The so-called "Lanchyn olistostrome" is rather a diapir that ascended from under the Stebnyk Formation.

Acknowledgements. Field researches have been supported by the Jagiellonian University (DS funds). A. Wysocka (Warsaw, Poland) and O. Hnylko (Lviv, Ukraine) provided critical reviewer comments, which are partly used in the improved version of the text. 


\section{REFERENCES}

Andreyeva-Grigorovich, A.S., Kulchytsky, A.Y., 1985. The age of evaporitic sequence of the Kalush-Golyn field (in Russian). In: Evaporites of Ukraine: 176-181. Naukova Dumka, Kiev.

Andreyeva-Grigorovich, A.S., Gruzman, A.D., Savitskaya, N.A., Trofimovich, N.A., 1995. Foraminifers and nannoplankton of Miocene deposits of the Carpathians and Precarpathian. Geological Society of Greece, Special Publication, 4: 159-162.

Andreyeva-Grigorovich, A.S., Kulchytsky, Y.O., Gruzman, A.D. Lozynyak, P.Y., Petrashkevich, M.I., Portnyagina, L.O., Ivanina, A.V., Smirnov, S.E., Trofimovich, N.A., Savitskaya, N.A., Shvareva, N.A., 1997. Regional stratigraphic scheme of Neogene formations on the Central Paratethys in the Ukraine. Geologica Carpathica, 48: 123-136.

Andreyeva-Grigorovich, A.S., Oszczypko, N., Ślączka, A., Savitskaya, N., Trofimovicz, N., 2003. Correlation of Late Badenian salt of the Wieliczka, Bochnia and Kalush areas (Polish and Ukrainian Carpathian Foredeep). Annales Societatis Geologorum Poloniae, 73: 67-89.

Andreyeva-Grigorovich, A.S., Oszczypko, N., Ślączka, A. Oszczypko-Clowes, M., Savitskaya, N.A., Trofimovicz, N., 2008a. New data on the stratigraphy of the folded Miocene Zone at the front of the Ukrainian Outer Carpathians. Acta Geologica Polonica, 58: 325-353.

Andreyeva-Grigorovich, A.S., Vashchenko, V.O., Hnylko, O.M., Kulyanda, M.J., Trofimovich, N.A., 2008b. Diachronous boundaries of Neogene formations in the Boryslav-Pokuttya and Sambir nappes of the Ukrainian Ciscarpathians (in Ukrainian with English summary). In: Biostratigraphic Fundamentals of Creating the Stratigraphic Schemes of the Phanerozoic of Ukraine. Proceedings of the Institute of Geological Sciences of the NAS of Ukraine (ed. P.F. Hozhyk): 199-204. Nora-print, Kyiv.

Andreyeva-Grigorovich, A.S., Vashchenko, V.O., Hnylko, O.M., Trofimovich, N.A., 2011. Stratigraphy of Neogene deposits of the Ukrainian Carpathians and Carpathian Foreland (in Ukrainian with English summary). Tektonika i Stratyhrafiya, 28: 67-77.

Bruderer, W., 1926. Les unités tectoniques bordières des Karpates Polonaises Orientales (in Polish with French summary). Sprawozdania Polskiego Instytutu Geologicznego, 3: 585-639.

Buatois, L.A., Mángano, M.G., 2007. Invertebrate ichnology of continental freshwater environments. In: Trace Fossils Concepts, Problems, Prospects (ed. W. Miller III): 285-323. Elsevier, Amsterdam.

Bujalski, B., 1930. Der geologische Bau des Karpatenvorlandes zwischen den Łomnica und Czeremosz-Flüssen (in Polish with German summary). Sprawozdania Państwowego Instytutu Geologicznego, 6: 235-292.

Bujalski, B., 1934. Profil doliny Prutu między Worochtą a Dobrotowem (in Polish). In: Przewodnik wycieczki. Polskie Towarzystwo Geologiczne, Oddział Lwów: 5-9.

Bujalski, B., 1938. Ogólna Mapa Geologiczna Polski w skali 1:100 000, arkusz 3, Nadwórna (in Polish). Państwowy Instytut Geologiczny Warszawa.

Burov, V.S., Vishnyakov, I.B., Mykyta, B.V., Khadykin, F.T., Shakin, V.A., 1976. Konglomeraty stebnitskoy svity Predkarpatya (in Russian). Geologiya i Geokhimiya Goryuchikh Iskopayemykh, 46: 34-40.

Burov, V.S., Glushko, V.V., Dolenko, G.N., 1978. Foredeep of the East Carpathians. In: Tectonics of the Carpathian Balkan Regions (ed. M. Mahel'): 217-220. Geological Institute of Dionyz Stúr, Bratislava.

Cizancourt, H., 1925. Note preliminaire sur l'avant-pays des Karpates Polonaises Orientales (in Polish with French summary). Biuletyn Stacji Geologicznej, 12: 1-49.

Einsele, G., 2000. Sedimentary Basins. Evolution, Facies and Sediment Budget. Springer, Berlin.

Eronen, J.T., Fortelius, M., Micheels, A., Portmann, F.T., Puolamäki, K., Janis, C.M., 2012. Neogene aridification of the Northern Hemisphere. Geology, 40: 823-826.
Fedushchak, M.J., 1962. Origin of the exotic conglomerates of the Vorotyshcha succession of the Ukrainian Fore-Carpathians. Publisher of the Ukrainian Academy of Sciences, Kiev.

Foster, G.L., Lear, C.H., Rae, J.W.B., 2012. The evolution of $\mathrm{pCO}_{2}$, ice volume and climate during the middle Miocene. Earth and Planetary Scientific Letters, 341-344: 243-254.

Gągała, Ł., Vergés, J., Saura, E., Malata, T., Ringenbach, J.C., Werner, P., Krzywiec, P., 2012. Architecture and orogenic evolution of the northeastern Outer Carpathians from cross-section balancing and forward modeling. Tectonophysics, 532-535: 223-241.

Garecka, M., Olszewska, B., 1997. Remarks on the stratigraphy of the Stebnik Suite in Poland (in Polish with English summary). Przegląd Geologiczny, 45: 794-798.

Garlicki, A., 1973. Results of study on the salt-bearing Miocene deposits south of Przemyśl (in Polish with English summary). Kwartalnik Geologiczny, 17 (1): 92-105.

Głowacki, E., Jurkiewicz, H., Karnkowski, P., 1966. Geology of the Przemyśl region in the light of deep drillings (in Polish with English summary). Kwartalnik Geologiczny, 10 (1): 211-249.

Gurzhyi, D.V., 1969. Lithology of Molasse of pre-Carpathian Area (in Russian). Naukova Dumka, Kiev.

Hilgen, F.J., Lourens, L.J., Van Dam, J.A., Beu, A.G., Boyes, A.F., Cooper, R.A., Krijgsman, W., Ogg, J.G., Piller, W.E., Wilson, D.S., 2012. The Neogene period. In: The Geologic Time Scale 2012 (eds. F.M. Gradstein, J.G. Ogg, M.D. Schmitz and G.M. Ogg): 923-978. Elsevier, Amsterdam.

Hizhniakov, A.V., 1954. Noviye sledy pozvonochnykh v nizhnemiotsenovykh otlozheniyakh Predkarpatya (in Russian). Geologicheskiy Sbornik Lvovskogo Geologicheskogo Obshchestva, 1: 177-179.

Hnylko, O.M., 2001. Olistostromovi vidkladi zchlenuvannya borslavsko-pokutskogo ta sambirskogo pokriviv ukrainskogo Predkarpattyam (in Ukrainian). In: Mizhnarodna nauikova Konferentsiya "Geologia Goryuchikh Iskopayemykh Ukrainy", Tezi Dopovidey: 58-59. Natsionalna Akademiya Ukrainy, Lviv.

Hnylko, O.M., 2004. Vnutrishnya zona (in Ukrainian). In: Karpatska naftogazonostna provintsya (ed. V.V. Kolodiy): 25-26. Natsionalnaya Akademia Nauk Ukrainy, Lviv, Kyiv.

Hnylko, O.M., 2012. Tectonic zoning of the Carpathians in terms of the terrane tectonics, Article 2. The Flysch Carpathian - ancient accretionary prism (in Ukrainian with English summary). Geodynamika, 12: 67-78.

Hnylko, O.M., 2014. Olistostromes in the Miocene salt-bearing folded deposits at the front of the Ukrainian Carpathian orogen. Geological Quarterly, 58 (3): 381-392.

Hnylko, M., Poberezhskij, A., Buchynskij, V., 2012. Geological and hydrogeological studies of the Polish-Ukrainian borderland (in Ukrainian). Geological Guide-book, Lviv 23-25.05.2012.

Ivanov, D.A., Ashraf, A.R., Mosbrugger, V., 2012. Late Oligocene and Miocene climate and vegetation in the Eastern Paratethys area (northeast Bulgaria), based on pollen data. Palaeogeography, Palaeoclimatology, Palaeoecology, 255: 342-360.

Jabłoński, E., 1923. La géologie de l'avant-pays des Carpathes entre Dobromil et Stryj (in Polish with French summary). Biuletyn Stacji Geologicznej, 2: 23-31.

Jabłoński, E., Weigner, S., 1925. Le bord des Carpathes entre Świca et Łomnica (in Polish with French summary). Biuletyn Stacji Geologicznej, 6: 1-79.

Jankowski, L., Kopciowski, R., Ryłko, W., eds., 2007. Geologica Map of the Outer Carpathians: Borderlands of Ukraine and Romania 1:200 000. Polish Geological Institute, Warszawa.

Kamieński, M., 1936. Sur les tufs volcaniques de l'avant-pays des Karpates (in Polish with French summary). Archiwum Mineralogiczne Towarzystwa Naukowego Warszawskiego, 12: 15-57.

Key, M.M., Jr., Zágoršek, K., Patterson, W.P., 2013. Paleoenvironmental reconstruction of the Early to Middle Miocene Central Paratethys using stable isotopes from bryozoan skeletons. International Journal of Earth Sciences, 102: 305-318. 
Khadykin, F.T., Shakin, V.A., 1976. Conglomerates of the Stebnik Formation of the Cis-Carpathians (in Ukrainian with English summary). Geologiya i Geokhimiya Goryuchikh Iskopayemykh, 46: 34-40.

Khrushchov, D.P., Kompanets, G.S., 1988. Litologia galogennykh i krasnotsvietnykh formatsyi Predkarpatya (in Russian). Naukova Dumka, Kiev.

Kolodiy, V.V., Boyko, H.J., Boychevska, L.E., eds., 2004 Carpathian Petroliferous Province. Ukrainian Centre for Publishing, Lviv-Kyiv.

Koltun, Y., Dudok, I., Kotarba, M., Adamenko, O., Pavlyuk, M., Burzewski, W., Stelmach, O., 2005. Geological setting and petroleum occurrence of the Starunia area, fore-Carpathian region, Ukraine. In: Polish and Ukrainian geological studies (2004-2005) at Starunia area of discoveries of Woolly Rhinoceroses (ed. M. Kotarba): 61-77. Polish Geological Institute, Warszawa.

Kováč, M., Nagymarosy, A., Oszczypko, N., Ślączka, A. Csontos, L., Marunteanu, M., Matenco, L., Márton, M., 1998. Palinspastic reconstruction of the Carpathian-Pannonian region during the Miocene. In: Geodynamic Development of the Western Carpathians (ed. M. Rakús): 189-217. Geological Survey of Slovak Republic, Bratislava.

Kováč, M., Andreyeva-Grigorovich, A.S., Brzobohatý, R., Fodor, L., Harzhauser, M., Oszczypko, N., Pavelić, D., Rögl, F., Saftić, B., Sliva, L., Stráník, Z., 2003. Karpatian paleogeography, tectonics and eustatic changes In: Karpatian - a Lower Miocene stage of the Central Paratethys (eds. R. Brzobohatý, I. Cicha, M. Kováč and F. Rögl): 49-72. Masaryk University, Brno.

Kroh, A., 2007. Climate changes in the Early to Middle Miocene of the Central Paratethys and the origin of its echinoderm fauna. Palaeogeography, Palaeoclimatology, Palaeoecology, 253: 169-207.

Krzywiec, P., Jochym, P., 1997. Characteristic of the Miocene subduction zone of the Polish Carpathians: results of flexura modelling (in Polish with English summary). Przegląd Geologiczny, 45: 785-792.

Kulchitsky, Y.O., Smirnov, S.E., 1996. Stratigraphical essay of Neogene of the Carpathians, Precarpathians and the south-western margin of East-European platform (in Ukrainian). Paleontologicheskiy Sbornik, 31: 56-66.

Kulchytsky, A.Y., Lozyniak, P., Petraskevych, M., 1997. Basic problems of geological structure and investigation of mineral resources in the Carpathian region (in Ukrainian with English summary). Memoirs of the Shevchenko Scientific Society, 1:25-45.

Kulchytsky, Y.O., Kulchytsky, A.Y., 1980. Finding of the maxilla of hollowhorned and the traces of vertebrates in the Miocene molasses of the Precarpathian and Transcarpathian foredeeps (in Russian with English summary). Geologicheskiy Sbornik, 17: 69-74.

Kulyanda, M., Hnylko, O., 2012. Verification of the stratigraphy of Neogene molasses of the Boryslav-Pokuttya and Sambir nappes in the north-western part of the Ukrainian Precarpathians (in Ukrainian with English summary). Geologiya Geokhimiya Goryuchikh Iskopayemykh, (1-2): 36-56.

Matskiv, D.V., Pukach, V.D., Hnylko, O.M., 2009. State Geological Map of Ukraine, 1:200 000, without Quaternary, M-35-XXXI, Nadvirna and Visheu de Sus sheets and explanation notes (in Ukrainian). Ukrainian State Geological Research Institute, Kyiv: 8-160.

Micu, M., 1982. Explanatory notes to lithotectonic profiles of Mio cene molasses from Central Moldovia (Eastern Carpathians, Romania). Veröffentlichungen des Zentralinstituts für Physik der Erde, 66: 117-136.

Ney, R., 1968. The role of the "Cracow bolt" in the geological history of the Carpathian fore-deep and in the distribution of oil and gas deposits (in Polish with English summary). Prace Geologiczne, 45: 1-82.

Ney, R., Burzewski, W., Bachleda, J., Górecki, W., Jakóbczak, K., Słupczyński, K., 1974. Outline of paleogeography and evolution of lithology and facies of Miocene layers of the Carpathian
Foredeep (in Polish with English summary). Prace Geologiczne, 82: $1-48$.

Olszewska, B., 1999. Biostratigraphy of Neogene in the Carpathian Foredeep in the light of new micropalaeontological data (in Polish with English summary). Prace Państwowego Instytutu Geologicznego, 168: 9-21.

Oszczypko, N., 1998. The Western Carpathian Foredeep - development of the foreland basin in front of the accretionary wedge and its burial history (Poland). Geologica Carpathica, 49: 415-431.

Oszczypko, N., Oszczypko-Clowes, M., 2003. The Aquitanian marine deposits in the basement of the Polish Western Carpathians and its paleogeographical and paleotectonic implications. Acta Geologica Polonica, 53: 101-122.

Oszczypko, N., Krzywiec, P., Popadyuk, I., Peryt, T., 2006. Carpathian foredeep basin (Poland and Ukraine): its sedimentary, structural, and geodynamic evolution. AAPG Memoir, 84: 261-318.

Oszczypko, N., Ślaczka, A., ytko, K., 2008. Tectonic subdivision of Poland: Polish Outer Carpathians and their foredeep (in Polish with English abstract). Przegląd Geologiczny, 56: 927-935.

Oszczypko, N., Uchman, A., Bubniak, I., 2012. Foreland provenance of thick conglomerates in the early stage of Carpathian Foredeep development: the case of the Sloboda Conglomerate (Lower Miocene), western Ukraine. Geological Quarterly, 56 (4): 789-902.

Oszczypko, N., Uchman, A., Bubniak, I., 2014. The Dobrotiv Formation (Miocene) in the Boryslav-Pokuttya and Sambir nappes of the Ukrainian Carpathians: a record of sedimentary environmental change in development of the Carpathian Foredeep basin. Geological Quarterly, 58 (3): 393-408.

Paul, K., Tietze, E., 1877. Studien in der Sandsteinzone der Karpathen. Jahrbuch der kaiserlich-königlichen Geologischen Reichsanstalt, 27: 33-130.

Picha, F.J., 1996. Exploring for hydrocarbons under thrust belts - a challenging new frontier in the Carpathians and elsewhere. AAPG Bulletin, 80: 1547-1564.

Pishvanova, L.S., 1969. Stratigraphical and facial distribution of foraminifera in Miocene deposits of the western part of Ukrainian SSR. Rocznik Polskiego Towarzystwa Geologicznego, 39 : 335-350.

Postma, G., 1990. Depositional architecture and facies of river and fan deltas: a synthesis. IAS Special Publication, 10: 13-27.

Rasser, M.W., Harzhauser, M., co-ordinators: Anistarenko, O.Y., Anistarenko, V.V., Bassi, D., Belak, M., Berger, J.-P., Bianchini, G., Čičic, S., Ćosović, V., Doláková, N., Drobne, K., Filipescu, S., Gürs, K., Hladilová, S., Hrvatovic, H., Jelen, B., Kasiński, J.R., Kováč, M., Kral, J.P., Marjanac, T., Marton, E., Mietto, P., Moro, A., Nagymarosy, A., Nebelsic, J., Nehyba, S., Ogorelec, B., Oszczypko, N., Pavelic, D., Pavlovec, R., Pavšic, J., Petrova, P., Piwocki, M., Poljak M., Pugliese, N., Redzerovic, R., Rifelj, H., Roetzel, R., Skaberne, D., Sliva, L., Standke, G., Tunis, G., Vass, D., Wagreich, M., Wessenligh, F., 2008. Palaeogene and Neogene. In: The Geology of Central Europe, 2: Mesozoic and Cenozoic (ed. T. McCann): 1031-1139. The Geological Society, London.

Royden, L.H., Burchfiel, B.C., 1989. Are systematic variations in thrust belt style related to plate boundary processes? (The Western Alps versus the Carpathians). Tectonics, 8: 51-61.

Smirnov, S.E., 2003. Paradoxes and problems of the stratigraphy of Precarpathian Foredeep (in Ukrainian with English summary). Zbirnyk Naukovykh Prac Ukrainskoho Derzhavnoho Geologichno-Rozviduvalnoho Instytuta UkrDGRI, 2: 63-69.

Smirnov, S.E., Savitska, N.A., Trofimovich, N.A., 2000. Problems of Miocene stratigraphy of Precarpathian Foredeep (in Ukrainian with English summary). Geologiya i Geokhimiya Goryuchykh Kopalyn. Problemy Stratigrafii, (1): 91-104.

Ślączka, A., Kruglov, S., Golonka, J., Oszczypko, N., Popadyuk, I., 2006. Geology and hydrocarbon resources of the Outer Carpathians, Poland, Slovakia, and Ukraine: general geology. AAPG Memoir, 84: 221-258. 
Świderski, B., 1925. Geological structure of the Pokucie Carpathians (in Polish with English summary). Biuletyn Stacji Geologicznej, 7: 1-132.

Tang, Z.-H., Ding, Z.-L., 2013. A palynological insight into the Miocene aridification in the Eurasian interior. Palaeoworld, 22 77-85.

Teisseyre, H., 1927. Der geologische Bau des Flyschrandes zwischen Nadwórna und Delyatyn (in Polish with German summary). Kosmos, 52A: 821-839.

Teisseyre, H., 1939. Résultats des recherchs géologiques du pétrole aux environs de Czerchwa et de Sprynia (feuille de Stary Sambor) (in Polish with French summary). Rocznik Polskiego Towarzystwa Geologicznego, 15: 29-41.

Tkachenko, O.F., 1961. Litologo-mineralogicheskaya kharekteristika otlozheniy nizhnego miotsena Predkarpatya (in Russian). Avtoreferat dissertatsii. Lvovskyi Gosudastvennyi Universitet, Lvov: 3-19.

Tołwiński, K., 1927. Géologie de la zone méridionale de l'avant-pays des Karpates Polonaises orientales (in Polish with French summary). Sprawozdania Polskiego Instytutu Geologicznego, 4: 346-272.

Tołwiński, K., 1937. Explication de la feuille Skole, livraison 2 (in Polish with French summary). Państwowy Instytut Geologiczny, Warszawa.

Tołwiński, K., 1950. The Pokutie Carpathians (in Polish with English summary). Acta Geologica Polonica, 1: 159-255.

Tye, R.S., Coleman, J.M., 1989. Depositional processes and stratigraphy of fluvially dominated lacustrine deltas: Mississippi delta plain. Journal of Sedimentary Research, 59: 973-996.

Vashchenko, V.O., Hnylko, O.M., 2003. Pro stratigrafiyu ta sedimentologichni osoblivosti neogenovykh molas Boryslavs'koPokuts'kogo pokryviv Ukrains'kogo Prykarpattya (in Ukrainian). Geologiya i Geokhimiya Goryuchykh Kopalyn, (1): 87-100.

Vialov, O.S., 1951. Skhema delenya miotsena Predkarpatya. Doklady Akademi Nauk SSSR, 78: 967-970.
Vialov, O.S., 1960. Novye iskopayemye sledy ptits $v$ miotsene Predkarpatia (in Russian). Doklady Akademii Nauk SSSR, 135: 1237-1239.

Vialov, O.S., 1965. Stratigraphya neogeneovykh molass Predkarpatya (in Russian). Naukova Dumka, Kiev.

Vialov, O.S., 1966. Sledy zhiznedeyatelnosti organizmov i ikh paleontologicheskoye znachenye (in Russian). Naukova Dumka, Kiev.

Vialov, O.S., Gavura, S.P., Chizh, I.T., 1981. Molassy Predkarpatya, Zakarpatya i ikh kharakteristika (in Russian). In: Istorija geologicheskogo razvitiya Ukrainskikh Karpat (ed. O.S. Vialov): 86-89. Naukova Dumka, Kiev.

Ziegler, P.A., Bertotti, G., Cloetingh, S., 2002. Dynamic processes controlling foreland development - the role of mechanical (de)coupling of orogenic wedges and forelands. Stephan Mueller Special Publication Series, 1: 17-56.

Zoetemeijer, R., Tomek, Č., Cloetingh, S., 1999. Flexural expression of European continental lithosphere under the Western Outer Carpathians. Tectonics, 18: 843-861.

Zuber, R., 1882. Studyja geologiczne we wschodnich Karpatach (in Polish). Kosmos, 7: 95-107, 183-190, 218-235.

Zuber, R., 1883. Geologische Beobachtungen in Ostkarpaten, II (in Polish with German summary). Kosmos, 8: 347-364, 425-440.

Zuber, R., 1885. Studyja geologiczne we wschodnich Karpatach, część IV (in Polish). Kosmos, 10: 345-397.

Zuber, R., 1888. Atlas geologiczny Galicji, Tekst do zeszytu drugiego (in Polish). Komisya Fizyjograficzna Akademii Umiejętności, Kraków.

Zuber, R., 1915. Zarys budowy północno-wschodnich Karpat (in Polish). Rozprawy i Wiadomości z Muzeum im. Dzieduszyckich, 1: $191-210$.

Zuber, R., 1918. Flisz i nafta (in Polish). Prace Naukowe Towarzystwo Naukowe we Lwowie. Dział 2, tom 2. Nakładem Towarzystwa Popierania Nauki Polskiej z funduszu Jędrzeja, Zofii i Bolesława Orzechowiczów, Lwów. 